\title{
LAND USE TRANSPORTATION INTERACTION: AN EXAMINATION OF THE 1995 NPTS DATA
}

\author{
By \\ Catherine L. Ross, Ph.D. \\ Professor of City Planning \\ and \\ Anne E. Dunning \\ Graduate Research Assistant
}

Georgia Institute of Technology

Graduate City Planning Program

College of Architecture

Atlanta, Georgia 30332-0155

USA

Prepared for:

U.S. Department of Transportation

Federal Highway Administration

October 1997 


\section{Land Use and Transportation Interaction: An Examination of the 1995 NPTS Data}

\section{Table of Contents}

EXECUTIVE SUMMARY $\ldots \ldots \ldots \ldots \ldots \ldots \ldots \ldots \ldots \ldots \ldots \ldots \ldots$

INTRODUCTION AND OVERVIEW $\ldots \ldots \ldots \ldots \ldots \ldots \ldots \ldots \ldots \ldots$

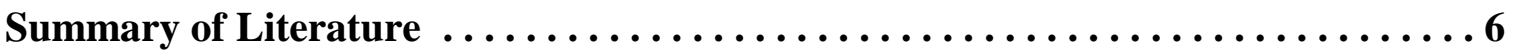

Key Terms and Definitions $\ldots \ldots \ldots \ldots \ldots \ldots \ldots \ldots \ldots \ldots \ldots \ldots \ldots$

Edge City, Second City, and Area Type 9

$\begin{array}{ll}\text { Transit Availability } & 10\end{array}$

$\begin{array}{ll}\text { Urban Sprawl } & 10\end{array}$

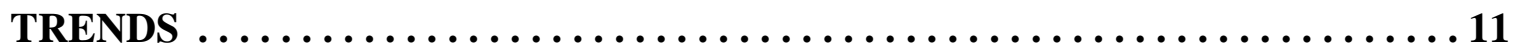

Comparison to Historical NPTS Data $\ldots \ldots \ldots \ldots \ldots \ldots \ldots \ldots \ldots \ldots$

New Variables Available for Land Use Study . . . . . . . . . . . . . 12

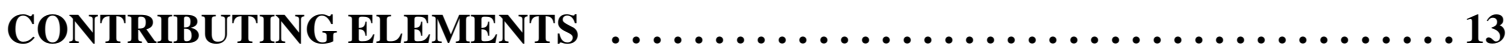

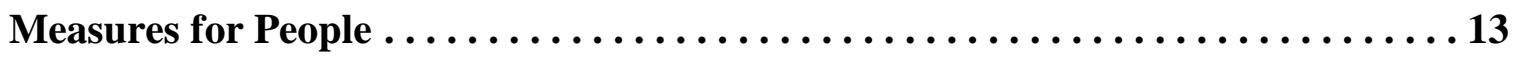

$\begin{array}{ll}\text { Population Density } & 13\end{array}$

Median Household Income/Poverty 17

Race and Hispanic Origin 20

$\begin{array}{ll}\text { Age } & 22\end{array}$

$\begin{array}{ll}\text { Education } & 25\end{array}$

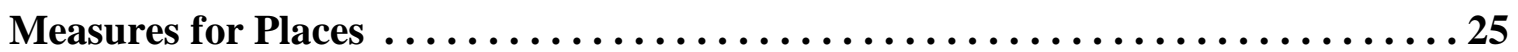

Area Type 25

Residential Density $\quad 30$

Age of Housing 36

$\begin{array}{ll}\text { Housing Tenure } & 37\end{array}$

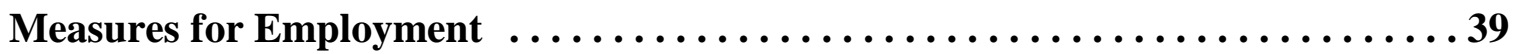

Employment Density 39

Retail Employment $\quad 42$ 
FINDINGS AND CONCLUSIONS $\ldots \ldots \ldots \ldots \ldots \ldots \ldots \ldots \ldots \ldots \ldots \ldots, \ldots \ldots$

Measures for People $\ldots \ldots \ldots \ldots \ldots \ldots \ldots \ldots \ldots \ldots \ldots \ldots \ldots \ldots \ldots \ldots 44$

Measures for Places $\ldots \ldots \ldots \ldots \ldots \ldots \ldots \ldots \ldots \ldots \ldots \ldots \ldots \ldots \ldots \ldots \ldots$

Area Type 45

Residential Density $\quad 46$

Age of Housing 47

$\begin{array}{ll}\text { Housing Tenure } & 47\end{array}$

Measures for Employment $\ldots \ldots \ldots \ldots \ldots \ldots \ldots \ldots \ldots \ldots \ldots \ldots \ldots \ldots, \ldots$

OTHER RESEARCH $\ldots \ldots \ldots \ldots \ldots \ldots \ldots \ldots \ldots \ldots \ldots \ldots \ldots \ldots \ldots \ldots, \ldots, \ldots \ldots \ldots$

REFERENCES $\ldots \ldots \ldots \ldots \ldots \ldots \ldots \ldots \ldots \ldots \ldots \ldots \ldots \ldots \ldots \ldots \ldots \ldots \ldots$ 


\section{Index of Tables}

TABLE 1: MILES DRIVEN LAST YEAR BY POPULATION DENSITY AND GENDER $\ldots \ldots \ldots \ldots \ldots 13$

TABLE 2: DRIVERS PER ADULT BY POPULATION DENSITY $\ldots \ldots \ldots \ldots \ldots \ldots \ldots \ldots \ldots \ldots \ldots$

TABLE 3: VEHICLES PER ADULT BY POPULATION DENSITY $\ldots \ldots \ldots \ldots \ldots \ldots \ldots \ldots \ldots \ldots \ldots$

TABLE 4: ONE-WAY WORK TRIP BY POPULATION DENSITY AND GENDER $\ldots \ldots \ldots \ldots \ldots \ldots \ldots$

TABLE 5: TRANSIT AVAILABILITY BY POPULATION DENSITY $\ldots \ldots \ldots \ldots \ldots \ldots \ldots \ldots \ldots \ldots$

TABLE 6: DISTANCE TO TRANSIT FROM THE HOUSEHOLD BY POPULATION DENSITY $\ldots \ldots \ldots 16$

TABLE 7: MODE OF TRANSPORTATION BY POPULATION DENSITY $\ldots \ldots \ldots \ldots \ldots \ldots \ldots \ldots \ldots$

TABLE 8: ANNUALIZED INDIVIDUAL TRAVEL BEHAVIOR BY POPULATION DENSITY $\ldots \ldots \ldots \ldots 17$

TABLE 9: BLOCK GROUP MEDIAN HOUSEHOLD INCOME BY AREA TYPE $\ldots \ldots \ldots \ldots \ldots \ldots \ldots 17$

TABLE 10: TRANSIT AVAILABILITY BY BLOCK GROUP MEDIAN HOUSEHOLD INCOME $\ldots \ldots \ldots 19$

TABLE 11: DISTANCE TO TRANSIT FROM HOUSEHOLD BY POVERTY STATUS . . . . . . . . . . . 19

TABLE 12: ANNUALIZED INDIVIDUAL TRAVEL BEHAVIOR BY HOUSEHOLD INCOME . . . . . . . 20

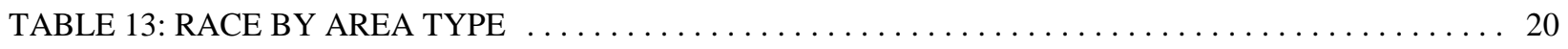

TABLE 14: TRANSIT AVAILABILITY BY RACE OR HISPANIC ORIGIN $\ldots \ldots \ldots \ldots \ldots \ldots \ldots \ldots 21$

TABLE 15: MODE OF TRANSPORTATION BY RACE OR HISPANIC ORIGIN $\ldots \ldots \ldots \ldots \ldots \ldots \ldots 21$

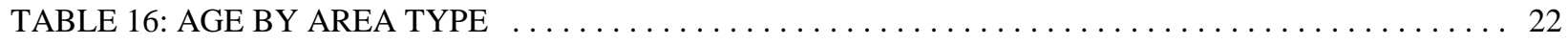

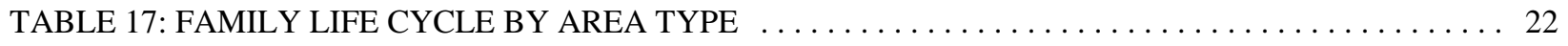

TABLE 18: ONE-WAY WORK TRIP BY AGE AND GENDER $\ldots \ldots \ldots \ldots \ldots \ldots \ldots \ldots \ldots \ldots \ldots \ldots$

TABLE 19: TRANSIT AVAILABILITY BY FAMILY LIFE CYCLE $\ldots \ldots \ldots \ldots \ldots \ldots \ldots \ldots \ldots \ldots$

TABLE 20: DISTANCE TO TRANSIT BY FAMILY LIFE CYCLE $\ldots \ldots \ldots \ldots \ldots \ldots \ldots \ldots \ldots \ldots 24$

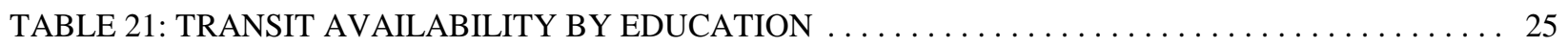

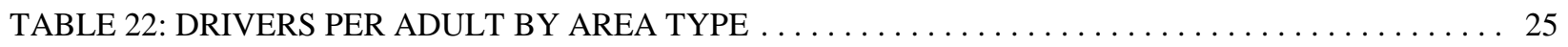

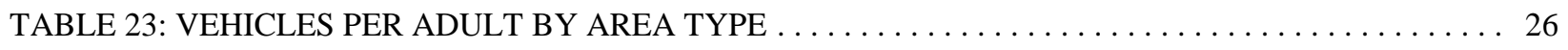

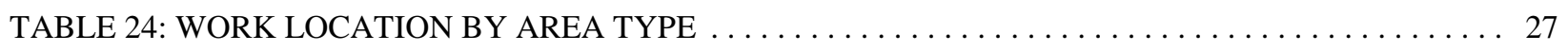

TABLE 25: ONE-WAY WORK TRIP BY AREA TYPE AND GENDER $\ldots \ldots \ldots \ldots \ldots \ldots \ldots \ldots \ldots 27$

TABLE 26: TRANSIT AVAILABILITY BY AREA TYPE $\ldots \ldots \ldots \ldots \ldots \ldots \ldots \ldots \ldots \ldots \ldots \ldots \ldots$

TABLE 27: DISTANCE TO TRANSIT FROM THE HOUSEHOLD BY AREA TYPE $\ldots \ldots \ldots \ldots \ldots \ldots 28$

TABLE 28: AUTOMOBILE COMMUTING BY AREA TYPE $\ldots \ldots \ldots \ldots \ldots \ldots \ldots \ldots \ldots \ldots \ldots \ldots$

TABLE 29: ANNUALIZED INDIVIDUAL TRAVEL BEHAVIOR BY AREA TYPE $\ldots \ldots \ldots \ldots \ldots \ldots$.

TABLE 30: BLOCK GROUP RESIDENTIAL DENSITY BY AREA TYPE $\ldots \ldots \ldots \ldots \ldots \ldots \ldots \ldots \ldots \ldots$

TABLE 31: MILES DRIVEN LAST YEAR BY RESIDENTIAL DENSITY AND GENDER $\ldots \ldots \ldots \ldots \ldots 31$

TABLE 32: ONE-WAY WORK TRIP BY RESIDENTIAL DENSITY AND GENDER $\ldots \ldots \ldots \ldots \ldots \ldots$

TABLE 33: TRANSIT AVAILABILITY BY RESIDENTIAL DENSITY $\ldots \ldots \ldots \ldots \ldots \ldots \ldots \ldots \ldots \ldots$

TABLE 34: DISTANCE TO TRANSIT FROM THE HOUSEHOLD BY RESIDENTIAL DENSITY . . . . . . 33

TABLE 35: MODE OF TRANSPORTATION BY RESIDENTIAL DENSITY $\ldots \ldots \ldots \ldots \ldots \ldots \ldots \ldots . \ldots$ 
TABLE 36: ANNUALIZED INDIVIDUAL TRAVEL BEHAVIOR BY RESIDENTIAL DENSITY $\ldots \ldots \ldots 34$

TABLE 37: WORK LOCATION BY RESIDENTIAL DENSITY $\ldots \ldots \ldots \ldots \ldots \ldots \ldots \ldots \ldots \ldots \ldots \ldots \ldots \ldots \ldots$

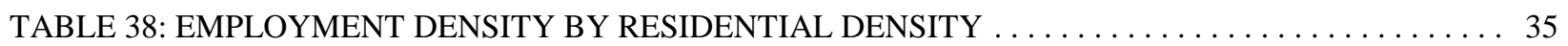

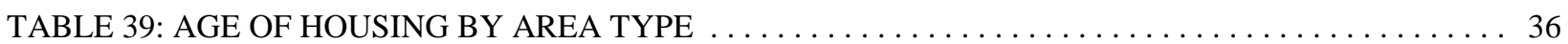

TABLE 40: BUS AVAILABILITY FOR RECENT BUILDS $\ldots \ldots \ldots \ldots \ldots \ldots \ldots \ldots \ldots \ldots \ldots \ldots \ldots$

TABLE 41: PERCENTAGE OF RENTER-OCCUPIED HOUSING BY AREA TYPE $\ldots \ldots \ldots \ldots \ldots \ldots 37$

TABLE 42: TRANSIT AVAILABILITY BY HOUSING TENURE $\ldots \ldots \ldots \ldots \ldots \ldots \ldots \ldots \ldots \ldots \ldots$

TABLE 43: DISTANCE TO TRANSIT BY HOUSING TENURE $\ldots \ldots \ldots \ldots \ldots \ldots \ldots \ldots \ldots \ldots$

TABLE 44: WORK TRACT EMPLOYMENT DENSITY BY HOME BLOCK GROUP AREA TYPE . . . . . . 39

TABLE 45: MILES DRIVEN LAST YEAR BY EMPLOYMENT DENSITY AND GENDER $\ldots \ldots \ldots \ldots .41$

TABLE 46: ONE-WAY WORK TRIP BY EMPLOYMENT DENSITY AND GENDER $\ldots \ldots \ldots \ldots \ldots .41$

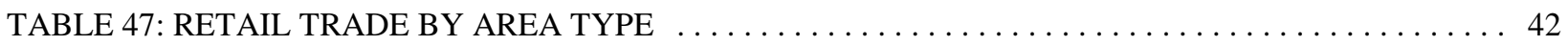

TABLE 48: MILES DRIVEN LAST YEAR BY RETAIL EMPLOYMENT AND GENDER $\ldots \ldots \ldots \ldots \ldots 43$

TABLE 49: ONE-WAY WORK TRIP BY RETAIL EMPLOYMENT AND GENDER $\ldots \ldots \ldots \ldots \ldots \ldots .43$

\section{Index of Figures}

FIGURE 1: PERSON TRIPS BY POPULATION DENSITY FOR 1990 AND $1995 \ldots \ldots \ldots \ldots \ldots \ldots \ldots 11$

FIGURE 2: MODE OF TRANSPORTATION BY POPULATION DENSITY $\ldots \ldots \ldots \ldots \ldots \ldots \ldots \ldots \ldots$

FIGURE 3: MEDIAN HOUSEHOLD INCOME BY AREA TYPE $\ldots \ldots \ldots \ldots \ldots \ldots \ldots \ldots \ldots \ldots \ldots$

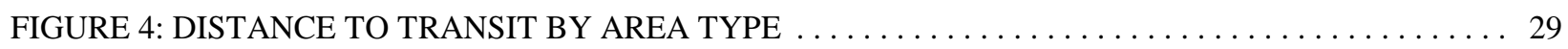

FIGURE 5: ANNUALIZED INDIVIDUAL TRAVEL BEHAVIOR BY RESIDENTIAL DENSITY . . . . . . . . 34

FIGURE 6: WORK TRACT EMPLOYMENT DENSITY BY HOME BLOCK GROUP AREA TYPE . . . . . . 40 


\section{EXECUTIVE SUMMARY}

There is currently a great deal of discussion about the interaction between land use and transportation. The 1995 NPTS provides some ability to investigate this question through the inclusion of variables that measure the interaction of land use and travel behavior. Population density is the primary quantifiable land use descriptor variable. Population density has been further manipulated to isolate area types (urban, second city, suburban, town and rural). Other variables that attempt to quantify land use include residential density and work tract employment density. Characteristics of the population or built environment such as race, age, income, and retail employment further identify land use impacts across different population groups.

Greater population density is associated with decreasing annual miles driven, greater bus availability, decreased dependency on single occupancy vehicles and increased use of transit. The private automobile is still the dominant mode of travel although African Americans, Asians and Hispanics are slightly more likely to use other modes of transportation.

Increasing population density is associated with fewer person trips, fewer person miles traveled, and fewer person miles per trip. Residents of densely populated areas report the fewest vehicle trips, vehicle miles traveled, and vehicle miles per trip. Less densely populated areas tend to have more drivers per adult and more vehicles per adult.

Second cities tend to follow national averages with regard to several transportation parameters, for example, drivers per adult, vehicles per adult, percent of persons working from home, and auto-dependency. Approximately $20 \%$ of second city residents go to work by a mode other than the private automobile. Residents of second cities report the highest number of person trips of any area type. Persons in suburban areas make the next highest number of person trips. A surprisingly high number of low-income residents live in second cities, which have limited transit availability.

Results of the 1995 NPTS identify the locational preferences of specific segments of the population. High-income households generally tended to locate in suburban areas while middle-income households are most often found in rural areas. Low-income households are generally found in urban or rural areas.

Distance to work and travel time to work decrease as the percentage of retail trade in an area increases. Urban areas have the smallest percentage of residents working in census tracts with over $25 \%$ participation in retail trade. Second cities have the highest percentage with $28.8 \%$ of residents working where more than $25 \%$ of jobs are in retail trade. Retail employment and employment density at the work census tract have some measurable correlations to travel behavior.

At the home block group, increasing housing density is associated with greater transit availability and closer proximity to transit. Bicycle and walk trips increase as residential density increases. Increasing residential density is also associated with increasing employment density. At residential densities between 100 and 1,499 housing units per square mile, people are less likely 
to work at jobs with no fixed workplace. Low residential density areas have the largest percentage of people working at home.

Residential density, retail employment, income, area type, and population density all provide important descriptors for transportation behavior and policy implementation. This National Personal Transportation Special Report carefully examines these and other aspects of people, places and employment that may link land use to transportation choices and behavior. Questions underlaying this analysis of that link include:

- What is the relationship between vehicle availability and urban sprawl?

- How do people travel in edge cities?

- How do population density, employment, access to goods and services, and transit availability affect household travel behavior?

- What land use characteristics at the residence and/or workplace end seem to be the best predictors of travel behavior?

- What impact does urban sprawl or dispersion have on travel behavior and transportation investment costs?

- What is the impact of edge cities on travel behavior?

- Have urban areas developed in ways that require us to travel in private vehicles and necessitate long vehicle trips (and vehicle emissions)?

- Do higher residential densities offer some chance of reducing vehicle trips and emissions?

- Does transit accessibility change people's travel behavior for all trips or only the work trip (peak period transit service vs. off-peak service)?

\section{INTRODUCTION AND OVERVIEW}

Transportation professionals increasingly look to land use as a possible explanatory factor of transportation behavior. The Federal Highway Administration (FHWA) designed the 1995 National Personal Transportation Survey to include several variables representing land use. The resulting data provides a basis to quantitatively explore land use and transportation interaction.

\section{Summary of Literature}

The following is a survey of current literature concerning the effect of land use on transportation. Studies that explore this relationship can help further our understanding of travel patterns and travel behavior now and in the future.

Pushkarev and Zupan's (1977) study on optimum density for transit types found that both high residential density and the high density and relative size of the trip-end destination (workplace) 
are major determinants of public transportation use. The study also concluded that clustering nonresidential floor-space in central business districts and placing moderate to high density residences ( 7 to 15 dwellings per acre) close to those clusters was the most effective in promoting transit use.

The reality of development through the latter part of this century is quite the opposite of that pattern. Low density and a doughnut hole of population and employment density in city centers increasingly characterize modern cities. Policies such as the Federal Highway Acts and the Standard Zoning Enabling Acts have drastically affected land use, expanding housing and employment into suburban areas. Instead of the Central Business District (CBD) containing the vast majority of a region's office floor-space, many new clusters of office buildings have sprung up in suburban areas (Pivo, 1990). Instead of dense clusters of buildings, as were found in the street grid of the traditional downtown, these suburban office complexes are spaced far apart with vast expanses of parking acreage in between. Often, the new complexes offer more real space for cars than for the people who drive them, and mass transit is atypical in these areas (Leinberger and Lockwood, 1986). This transit and pedestrian unfriendly environment, coupled with the fact that these complexes were designed as single-use centers, means shopping, dining, and other day-to-day activities tend to be accessible by auto.

In addition, recent years have brought an increasing awareness of the trend of American cities to form nodes of urban activity in the midst of suburbs surrounding central cities. These nodes have transferred travel activity from radial activity focused on the concentrated central core of a city to tangential movement between the outer nodes. Joel Garreau's definitive book, Edge City: Life on the New Frontier, characterizes these nodes as edge cities and explains this growing phenomenon.

According to research conducted in the 1980's, the migration of white-collar office and service job centers to the suburbs resulted in an increase rather than a decrease in travel time and distance to work. Robert Cervero (1989) contends this is an outgrowth of "jobs-housing spatial imbalance" brought on by factors beyond the simple lack of land-use planning. Possible causes include fiscal and exclusionary zoning, two wage-earner households tending to locate close to one workplace and not the other, and the fast pace of job-turnover coupled with an unwillingness to relocate close to a new job (Cervero, 1989).

In contrast, Gordon and Richardson emphasized in the 1990 NPTS Special Report "Geographic Factors Explaining Worktrip Length Changes" that average work trip duration either fell slightly or grew by much smaller percentages than distances. The suburbanization of jobs and residences has allowed people to live away from activity centers and use roads with less congestion than city streets. With longer distances but less congestion, travel time has not suffered from sprawl ${ }^{1}$.

Another study of five communities in the San Francisco Bay area did not focus explicitly on trip length but looked instead at the number of trips by mode. A primary finding was that land use characteristics of the neighborhoods (where person trips were generated) were not associated with number of person trips made, but were associated with transit and non-motorized trips (Kitamura et al, 1997). High density was found to be associated with lower fractions of auto 
trips, and higher percentages of non-motorized trips. a community was found to be statistically correlated with an increase in non-motorized trips. Eight attitudinal factors were entered into the analysis. The factors included pro-environment, pro-transit, automotive mobility, time pressure, and urban form and added increasing explanatory power to the models used to predict travel mobility. This led researchers to conclude that "attitudes are at least more strongly, and perhaps more directly associated with travel than are land use characteristics." (Kitamura et al, p. 154).

Many studies have shown similar findings with regard to density and its correlation to transit usage versus auto usage and also identified other elements which contribute to transportation mode choice. In addition to low densities and ample free parking, suburban business areas are characterized by a single dominant land use: office space. It is believed that mixed-used developments, combining offices, shops, restaurants, banks and other activities may be important to relieving automobile congestion by reducing the number of trips. In pedestrian-friendly mixed-use suburban activity centers, it is hypothesized that walking can take the place of noonor peak-hour auto trips to conduct errands.

In her review of density/travel pattern literature, Ruth Steiner identifies assumptions that underlie the views of the proponents of high-density, mixed-used land use patterns (Steiner, 1994). These assumptions include:

- People are willing to move into high density developments

- Travel patterns will change once people locate in a high density development

- People in high density developments will make fewer and shorter auto trips

- People in high density developments will walk and use transit more frequently

Another study attempting to account for both density and socioeconomic makeup came to the conclusion that "population density, employment density, and land-use mix are related to mode choice [even] when non-urban-form [socioeconomic] factors are controlled" (Frank and Pivo, 1994). The study went on to test the hypothesis that the relationship of population density, employment density and mode choice is non-linear, enabling the identification of thresholds of density where shifts from one mode (auto) to others (transit or walking) occur. Significant shifts from auto use to walking or transit occur at certain employment density levels (20-75 employees per acre, and at $>125$ employees per acre). For shopping trips, population densities need to exceed 13 persons per acre before a significant shift from auto use to walking or transit occurs (Frank and Pivo, 1994).

\section{$\underline{\text { Key Terms and Definitions }}$}

Several conventions were developed to facilitate research with the 1995 NPTS data. These conventions include the following definitions and explanations. 


\section{Edge City, Second City, and Area Type}

Joel Garreau defined five factors that determine an edge city:

- "Has five million square feet or more of leasable office space--the workplace of the Information Age,

• "Has 600,000 square feet or more of leasable retail space,

• "Has more jobs than bedrooms,

- "Is perceived by the population as one place,

. "Was nothing like 'city' as recently as thirty years ago ${ }^{2} . "$

People often know where these edge cities exist in their own states, but quantitatively defining an edge city for the purposes of the NPTS poses a challenge. NPTS variables deal primarily with people, rather than spaces; hence, population, household, and employment densities can be used to explain these urban phenomena, rather than floor space and community perceptions.

David R. Miller and Ken Hodges of Claritas, Inc. established a standard for defining urbanization categories using relational population densities ${ }^{3}$. Under this system, Claritas defines a grid system across the United States based on 1/30th of a degree latitude and longitude, which amounts to roughly 900,000 cells of about four square miles each. The total population of a given cell and its eight surrounding cells (a $3 \times 3$ grid) divided by the total area of all nine cells determines the given cell's grid density. Claritas then ranks all of the grid cell densities for the nation into one hundred equal groups (a scale of 0 to 99).

The highest grid cell density in a 5-mile radius ( $5 \times 5$ grid, excluding the corners) determines the local density maximum in an area. Population centers emerge where grid cell densities only decrease moving away from a local maximum and no other local maximum with a greater density appears in closer proximity.

Area type classifications depend on the calculated grid cell densities and population center densities. Simple grid cell densities define rural areas (grid cell densities less than or equal to 19) and small towns (grid cell densities greater than or equal to 20 and less than or equal to 39). This classification results in groupings similar to the groups created by the Urbanized Area definition of 1,000 persons per square mile minimum. Claritas associates population center densities greater than 79 with urban areas; second cities comprise remaining population center densities. Areas around second city and urban areas form suburban areas. Lines of different slopes distinguish suburban areas around the population centers of second cities and urban areas. 
Area Type Determination Calculations

\begin{tabular}{|c|c|}
\hline Area Type & Determination Calculation \\
\hline Rural Area & $\mathrm{GCD} \leq 19$ \\
\hline Town & $20 \leq \mathrm{GCD} \leq 39$ \\
\hline Urban Area & $\begin{array}{c}\mathrm{PCD} \geq 79 \text { (urban population center) } \\
\text { and } \\
\mathrm{GCD} \geq 40 \text { (not town or rural) } \\
\text { and } \\
\mathrm{GCD} \geq 0.80 \cdot \mathrm{PCD}+9.8\end{array}$ \\
\hline Second City & $\begin{array}{c}\text { PCD }<79 \text { (not an urban population center) } \\
\text { and } \\
\text { GCD } \geq 40 \text { (not town or rural) } \\
\text { and } \\
\text { GCD } \geq 1.7368 \cdot \operatorname{PCD}-64.208\end{array}$ \\
\hline Suburban Area & $\begin{array}{c}\mathrm{GCD} \geq 40 \\
\text { and } \\
\text { Area } \neq \text { Urban Area } \\
\text { and } \\
\text { Area } \neq \text { Second City }\end{array}$ \\
\hline $\begin{array}{c}\text { GCD = Grid Cell Density } \\
\text { PCD = Population Center Density }\end{array}$ & $\begin{array}{l}\text { Source: "A Population Density Approach to } \\
\text { Incorporating an Urban-Rural Dimension into Small } \\
\text { Area Lifestyle Clusters" by Miller and Hodges }\end{array}$ \\
\hline
\end{tabular}

Second cities differ from Garreau's edge cities in that second cities can be quantitatively defined and rely entirely on contextual population densities; whereas, edge cities receive their classifications from community perceptions and measurements of space. Existing political definitions of local borders do not affect the NPTS area type classification system.

\section{Transit Availability}

Transit availability is defined as bus availability. The 1995 NPTS assumes that the bus is the basic form of transit. Streetcar, subway, and commuter rail are assumed to exist only where a bus system has been established.

\section{Urban Sprawl}

Urban sprawl describes the tendency for people who associate themselves with an urban center to live farther and farther away from that urban center. Sprawl is difficult to define quantitatively. The area type coding provided by Claritas offers a good proxy for sprawl. Population density defines the edge of an urban area's impact on population, as opposed to political boundaries which may not indicate the true form of population dynamics. Suburban areas, as defined by Claritas, are assumed to be associated with an urban area or a second city. Suburbs can, therefore, be classified as the sprawled outer edges of the urban area. In this analysis, travel behavior found in suburbs and second cities represent the effects of urban sprawl. 


\section{TRENDS}

The 1995 Nationwide Personal Transportation Survey provided groundbreaking precedent to provide new ways of exploring the effects of land use on travel. The new land use survey questions, combined with improvements such as travel diaries, establishes a standard for future studies.

\section{Comparison to Historical NPTS Data}

Previous NPTS surveys have provided data on characteristics such as area densities, populations, and differences between central cities and areas outside central cities. Population density provides the greatest comparison between past surveys and the 1995 NPTS

FIGURE 1: PERSON TRIPS BY POPULATION DENSITY FOR 1990 AND 1995

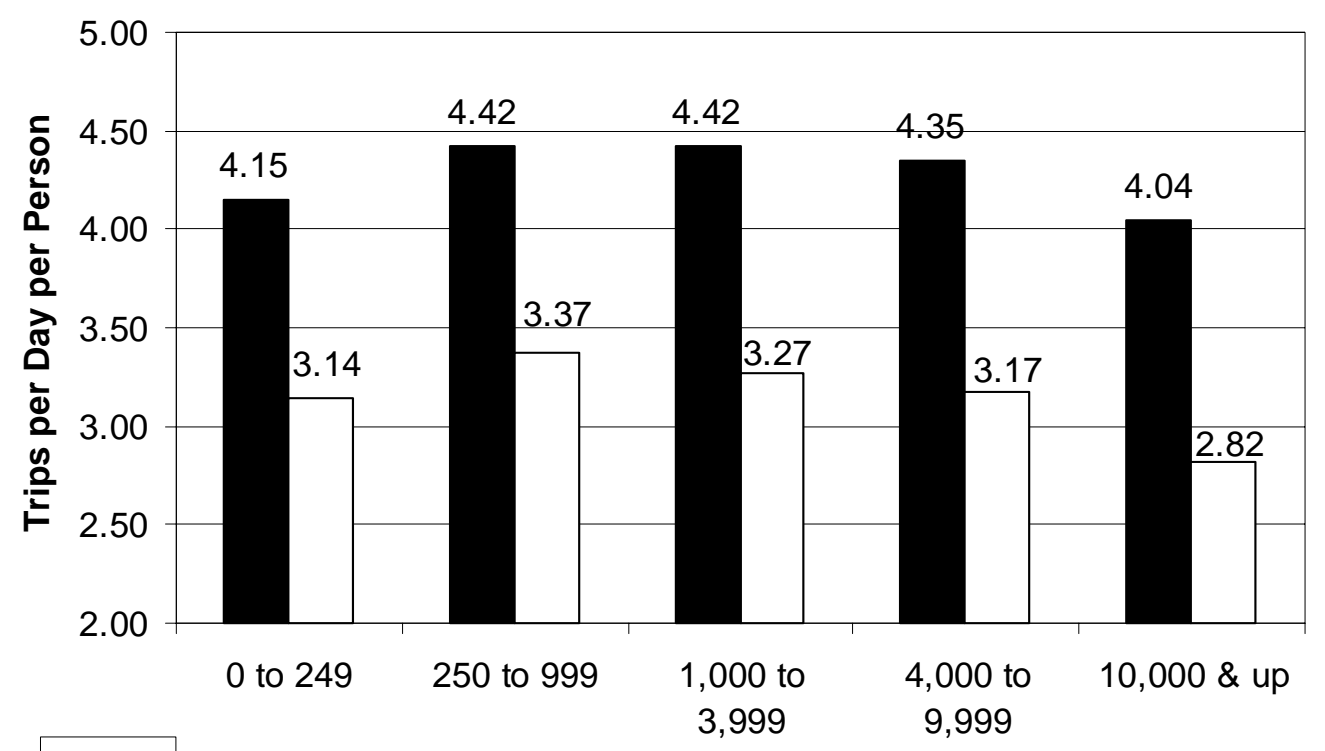

1995

1990

Population Density (People/Square Mile)

In the 1990 NPTS special report "Travel by Households without Vehicles ${ }^{4}$," Charles Lave and Richard Crepeau found that the number of person trips per day for the total NPTS sample peaked at population densities between 250 and 999 people per square mile. Data values between 1990 and 1995 show an overall increase in the number of trips people took across all population densities. The numbers are difficult to compare, but comparison of person trips to population density remains remarkably similar. In 1995, people tended to make more person trips per day in medium-density areas. 
FIGURE 2: MODE OF TRANSPORTATION BY POPULATION DENSITY

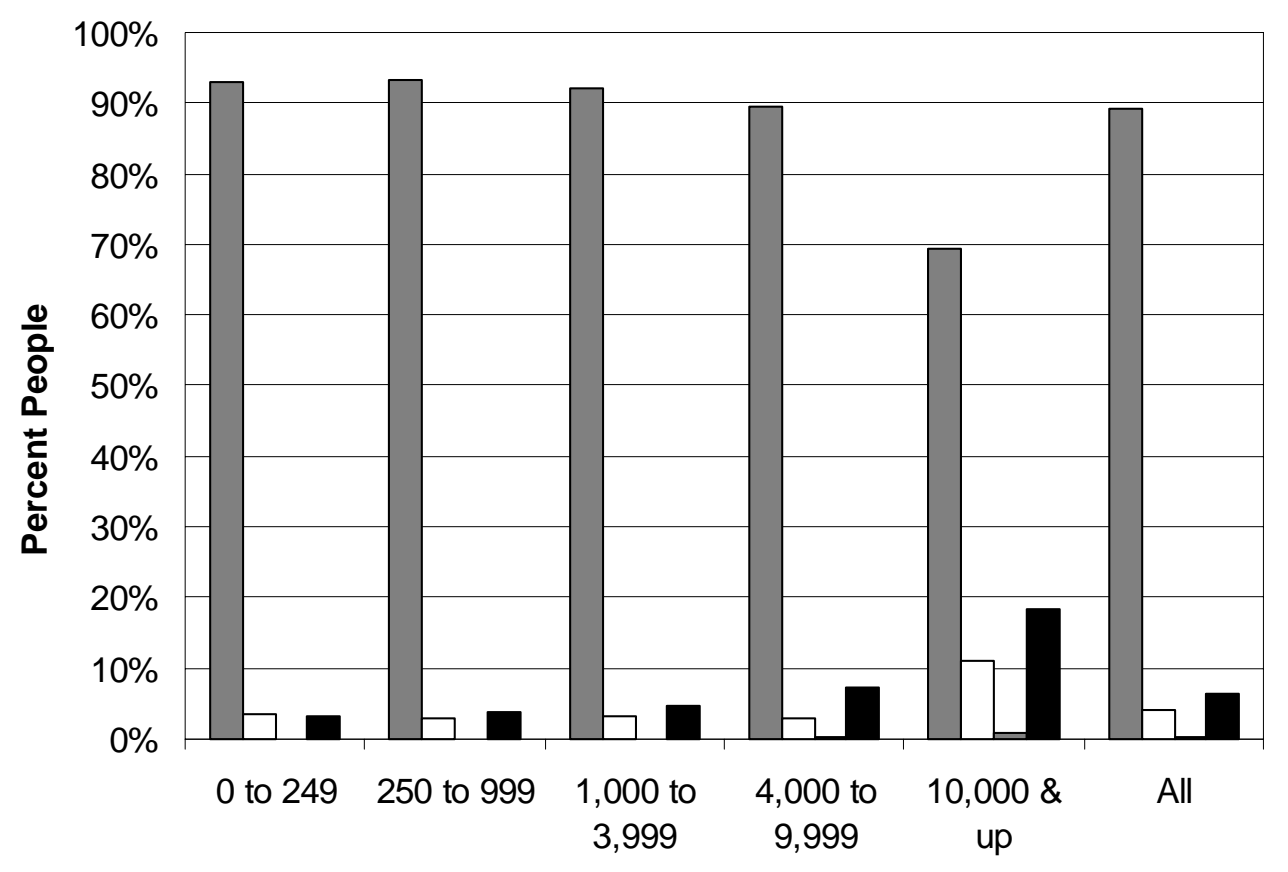

Population Density (People/Square Mile)

$\square$ Private Vehicle $\square$ Public Transit $\square$ Taxi $\square$ Bicycle/Walk

Mode choice trends have also remained consistent in the 1995 NPTS. In the 1990 Special Report "Recent Nationwide Declines in Carpooling,", Erik Ferguson found trends of decreasing private vehicle use as population density increases. In addition, transit use increased as population density increased. The data in Figure 2 indicate that these trends remain constant in the 1995 NPTS.

\section{New Variables Available for Land Use Study}

Beyond population density, the 1995 NPTS began exploring more aspects of the developed environment than previous surveys. Several census categories can be applied to the NPTS data to offer more information on social characteristics. This report focuses on the following land use and population characteristics: 


\begin{tabular}{|c|c|c|}
\hline Measures for People & Measures for Places & Measures for Employment \\
\hline Population density & Area Type & Employment density \\
\hline Income & Residential density & Retail employment \\
\hline Poverty status & Age of Housing & \\
\hline Race/ethnicity mix & Housing tenure & \\
\hline Hispanic origin & & \\
\hline Age & & \\
\hline Educational attainment & & \\
\hline Retail employment & & \\
\hline
\end{tabular}

The 1995 NPTS also includes self-reports of transit accessibility, household vehicle availability, and customer evaluations of highway and public transportation.

\section{CONTRIBUTING ELEMENTS}

The issues, terms, methodologies, and trends discussed to this point all contribute to the analysis of the 1995 Nationwide Personal Transportation Survey data. The previous section identified historical trends in NPTS data. The literature review has established the current background of intellectual debate regarding land use and transportation. Using these contexts and the concepts of the key terms defined earlier, this report will now employ the new variables available for land use study to analyze the interaction of land use and transportation. This section divides these analyses into categories of measures for people, places, and employment.

\section{Measures for People}

\section{Population Density}

Traditionally, analysts have used population density and MSA size to measure the effects of land use on different aspects of transportation. Population density provides a good indicator, for instance, of annual miles driven.

TABLE 1: MILES DRIVEN LAST YEAR BY POPULATION DENSITY AND GENDER

\begin{tabular}{|c|c|c|c|c|}
\hline \multirow[b]{3}{*}{ People per Mile } & \multicolumn{4}{|c|}{ Annual Miles Driven } \\
\hline & \multicolumn{2}{|c|}{ Male } & \multicolumn{2}{|c|}{ Female } \\
\hline & Mean & Median & Mean & Median \\
\hline 0 to 249 & 17,991 & 14,000 & 10,607 & 9,000 \\
\hline 250 to 999 & 17,670 & 15,000 & 10,288 & 9,000 \\
\hline 1,000 to 3,999 & 15,415 & 12,000 & 8,976 & 8,000 \\
\hline 4,000 to 9,999 & 14,316 & 12,000 & 8,307 & 6,500 \\
\hline 10,000 \& up & 11,479 & 9,000 & 7,276 & 5,000 \\
\hline
\end{tabular}

The first table shows that high population densities are associated with driving fewer miles annually. Males typically drive 1.5 to nearly 2 times as many miles as females do, but the correlation between density and annual miles driven holds true for both genders at all population 
densities. Presumably, low population density is associated with increased distance between destinations and greater miles driven each year.

TABLE 2: DRIVERS PER ADULT BY POPULATION DENSITY

\begin{tabular}{|c|c|c|c|c|c|c|}
\hline \multirow[b]{2}{*}{ Drivers per Adult } & \multicolumn{6}{|c|}{ People per Mile $^{2}$} \\
\hline & 0 to 249 & $\underline{250}$ to 999 & 1,000 to 3,999 & 4,000 to 9,999 & $\underline{10,000 \& \text { up }}$ & $\underline{\text { Total }}$ \\
\hline Less than One & $10.90 \%$ & $10.20 \%$ & $12.60 \%$ & $15.70 \%$ & $36.80 \%$ & $15.80 \%$ \\
\hline One Driver & $82.80 \%$ & $84.80 \%$ & $82.40 \%$ & $81.10 \%$ & $62.20 \%$ & $79.90 \%$ \\
\hline More than One & $6.20 \%$ & $5.00 \%$ & $5.00 \%$ & $3.20 \%$ & $0.90 \%$ & $4.30 \%$ \\
\hline Total & $100.00 \%$ & $100.00 \%$ & $100.00 \%$ & $100.00 \%$ & $100.00 \%$ & $100.00 \%$ \\
\hline
\end{tabular}

Areas of high population density do not follow the same trends in drivers per adult as block groups with lower densities. The most densely populated areas have the highest percentage of residents with less than one driver per adult. In areas with population densities above 10,000 people per square mile, approximately $36.8 \%$ of residents have less than one driver per adult. This ratio differs greatly from the average of $15.8 \%$ across all density categories. For density levels between 4,000 and 9,999 people per square mile, $15.7 \%$ of the people have less than one driver per adult. In contrast, $82.8 \%$ of the people have one driver per adult in the 0 to 249 people per square mile density level while only $62.2 \%$ have one driver per adult at population densities above 10,000 people per square mile.

\section{TABLE 3: VEHICLES PER ADULT BY POPULATION DENSITY}

\begin{tabular}{|c|c|c|c|c|c|c|}
\hline \multirow[b]{2}{*}{ Vehicles per Adult } & \multicolumn{6}{|c|}{ People per Mile ${ }^{2}$} \\
\hline & $\underline{0}$ to 249 & $\underline{250}$ to 999 & 1,000 to 3,999 & $\underline{4,000 \text { to } 9,999}$ & 10,000 \& up & Total \\
\hline Less than One & $17.10 \%$ & $17.60 \%$ & $20.00 \%$ & $27.10 \%$ & $53.60 \%$ & $25.10 \%$ \\
\hline One Vehicle & $57.50 \%$ & $63.30 \%$ & $64.80 \%$ & $61.20 \%$ & $41.50 \%$ & $59.10 \%$ \\
\hline More than One & $25.50 \%$ & $19.00 \%$ & $15.20 \%$ & $11.70 \%$ & $4.90 \%$ & $15.80 \%$ \\
\hline Total & $100.00 \%$ & $100.00 \%$ & $100.00 \%$ & $100.00 \%$ & $100.00 \%$ & $100.00 \%$ \\
\hline
\end{tabular}

The number of vehicles per adult follows trends similar in most respects to those patterns set by the number of drivers per adult. Population densities of over 10,000 people per square mile have the highest percentage $(53.6 \%)$ of adults with less than one vehicle. At density levels under 250 people per square mile, only $17.1 \%$ of adults have less than one vehicle. Conversely, $25.5 \%$ of adults in the lowest-density areas have more than one vehicle, but only $4.9 \%$ of adults living in population densities above 10,000 people per square mile own multiple vehicles. Across all density levels, an average of $15.8 \%$ of all adults have more than one vehicle. 
TABLE 4: ONE-WAY WORK TRIP BY POPULATION DENSITY AND GENDER

\begin{tabular}{|c|c|c|c|c|c|c|c|c|}
\hline \multirow{3}{*}{$\frac{\text { People per }}{\text { Mile }^{2}}$} & \multicolumn{4}{|c|}{ Distance to Work (Miles) } & \multicolumn{4}{|c|}{ Time to Work (Minutes) } \\
\hline & \multicolumn{2}{|c|}{ Male } & \multicolumn{2}{|c|}{ Female } & \multicolumn{2}{|c|}{ Male } & \multicolumn{2}{|c|}{ Female } \\
\hline & Mea & Media & Mea & Media & Mea & Media & Mea & Media \\
\hline & $\underline{\mathbf{n}}$ & $\underline{\mathbf{n}}$ & $\underline{\mathbf{n}}$ & $\underline{\mathbf{n}}$ & $\underline{\mathbf{n}}$ & $\underline{\mathbf{n}}$ & $\underline{\mathbf{n}}$ & $\underline{\mathbf{n}}$ \\
\hline 0 to 249 & 17 & 12 & 13 & 10 & 24 & 20 & 20 & 15 \\
\hline 250 to 999 & 17 & 10 & 12 & 8 & 24 & 20 & 20 & 15 \\
\hline 1,000 to 3,999 & 14 & 9 & 11 & 7 & 22 & 17 & 19 & 15 \\
\hline 4,000 to 9,999 & 12 & 8 & 9 & 6 & 23 & 20 & 20 & 15 \\
\hline 10,000 \& up & 11 & 7 & 9 & 5 & 26 & 20 & 26 & 20 \\
\hline
\end{tabular}

Table 4 shows that people living in low-density areas generally travel longer distances to work, and their commute times are longer than the commute times of their higher population density counterparts. As population density increases, commute times and distances decrease slightly where population densities are less than 10,000 people per square. At densities greater than 10,000 people per square mile, distances continue to decrease, but trip times suddenly increase. This increase likely indicates that short distances cannot alleviate long commute times in densely populated and congested areas. An alternative explanation is that this increase reflects the additional travel time associated with transit use.

At all density levels, women have shorter commute distances and times, indicating that households are located closer to where women work than to where men work. It is not clear whether households locate closer to where women work or if women find jobs closer to home.

TABLE 5: TRANSIT AVAILABILITY BY POPULATION DENSITY

Transit Availability

\begin{tabular}{rrrrl} 
People per Mile $^{2}$ & \multicolumn{1}{c}{\begin{tabular}{c} 
Bus Service \\
\cline { 5 - 5 }
\end{tabular}} & No Bus & All \\
\cline { 2 - 4 } 0 to 249 & $20.1 \%$ & $79.9 \%$ & $100.0 \%$ \\
250 to 999 & $41.0 \%$ & $59.0 \%$ & $100.0 \%$ \\
1,000 to 3,999 & $69.4 \%$ & $30.6 \%$ & $100.0 \%$ \\
4,000 to 9,999 & $88.8 \%$ & $11.2 \%$ & $100.0 \%$ \\
10,000 \& up & $98.0 \%$ & $2.0 \%$ & $100.0 \%$ \\
Total & $63.4 \%$ & $36.6 \%$ & $100.0 \%$
\end{tabular}

As shown in Table 5, transit (bus) availability increases with increased population densities. In the least densely populated areas, bus service is available to only $20.1 \%$ of the population. This percentage increases over fourfold to $98.0 \%$ in areas with population densities of 10,000 people per square mile and greater. 
TABLE 6: DISTANCE TO TRANSIT FROM THE HOUSEHOLD BY POPULATION DENSITY

\section{Distance to \\ Transit}

Less than 1 mile

.1 to .24 mile

.25 to .49 mile

.5 to .99 mile

1 mile \& up $57.4 \%$

Total $100.0 \%$

\section{People per Mile ${ }^{2}$}

0 to 249250 to $999 \quad 1,000$ to $3,999 \quad 4,000$ to $9,999 \quad 10,000$ \& up All

$18.5 \% \quad 20.1 \%$

$2.4 \% \quad 5.6 \%$

$3.0 \% \quad 6.5 \%$

$29.6 \%$

$38.2 \%$

$100.0 \%$
$26.0 \%$

$13.0 \%$

$10.4 \%$

$35.1 \%$

$15.5 \%$

$100.0 \%$

$\begin{array}{rrr}38.4 \% & 57.9 \% & 36.0 \% \\ 17.4 \% & 18.3 \% & 14.3 \% \\ 13.3 \% & 11.2 \% & 10.8 \% \\ 25.2 \% & 11.3 \% & 25.1 \% \\ 5.7 \% & 1.3 \% & 13.8 \% \\ 100.0 \% & 100.0 \% & 100.0 \%\end{array}$

As shown in Table 6, the most densely populated areas have transit located most closely to the household. For areas with population densities of 4,000 people per square mile and greater, the largest share of transit is located within .1 mile of the household. As population density decreases, the distance from transit to the residence increases; this is true except for transit located less than .1 mile from the household. People living in the least densely populated areas live farthest from transit, with over half of transit located at least .5 mile away from the household.

TABLE 7: MODE OF TRANSPORTATION BY POPULATION DENSITY

\begin{tabular}{|c|c|c|c|c|c|c|}
\hline \multirow[b]{2}{*}{ Mode } & \multicolumn{6}{|c|}{ People per Mile ${ }^{2}$} \\
\hline & $\underline{0}$ to 249 & $\underline{250 \text { to } 999}$ & 1,000 to 3,999 & 4,000 to 9,999 & $10,000 \&$ up & All \\
\hline Private Vehicle & $93.1 \%$ & $93.3 \%$ & $92.0 \%$ & $89.6 \%$ & $69.4 \%$ & $89.3 \%$ \\
\hline Public Transit & $3.5 \%$ & $2.9 \%$ & $3.1 \%$ & $3.0 \%$ & $11.0 \%$ & $4.0 \%$ \\
\hline Taxi & $0.0 \%$ & $0.1 \%$ & $0.1 \%$ & $0.2 \%$ & $1.0 \%$ & $0.2 \%$ \\
\hline Bicycle/Walk & $3.3 \%$ & $3.8 \%$ & $4.8 \%$ & $7.2 \%$ & $18.5 \%$ & $6.5 \%$ \\
\hline Total & $100.0 \%$ & $100.0 \%$ & $100.0 \%$ & $100.0 \%$ & $100.0 \%$ & $100.0 \%$ \\
\hline
\end{tabular}

Beyond describing trip characteristics, population density also affects mode choice preferences. As shown in Table 7, the private vehicle dominates as the preferred mode of transportation. Between 4,000 and 9,999 people per square mile, people use private vehicles $89.6 \%$ of the time. Above 10,000 people per square mile, private vehicle utilization drops dramatically to $69.4 \%$. Areas with population densities less than 250 people per square mile possess the highest share of private vehicle usage, which may be attributable to the few mode choice options available in low-density areas. In contrast, high population density reduces the private vehicle's popularity. Usage of alternative modes of transportation drastically increases for population densities over 10,000 people per square mile, while private vehicle utilization drops by roughly $25 \%$ to $69.4 \%$. Notably, bicycling and walking (18.5\%) outperforms public transit (11.0\%) at the highest density. This demonstrated preference merits further exploration of investments for urban pedestrian environments and bicycle right-of-way. 
TABLE 8: ANNUALIZED INDIVIDUAL TRAVEL BEHAVIOR BY POPULATION DENSITY

\begin{tabular}{|c|c|c|c|c|c|c|}
\hline \multirow[b]{2}{*}{ Population } & \multicolumn{6}{|c|}{ Annualized Individual Travel Behavior } \\
\hline & Person & Person Miles & Person Miles & Vehicle & $\underline{\text { Vehicle Miles }}$ & Vehicle Miles \\
\hline Density & Trips & Traveled (PMT) & per Trip & Trips & Traveled (VMT) & per Trip \\
\hline 0 to 249 & 1,515 & 16,900 & 11 & 958 & 10,560 & 11 \\
\hline 250 to 999 & 1,614 & 15,345 & 10 & 1,025 & 9,762 & 10 \\
\hline 1,000 to 3,999 & 1,615 & 14,414 & 9 & 1,020 & 8,458 & 8 \\
\hline 4,000 to 9,999 & 1,586 & 12,837 & 8 & 968 & 7,827 & 8 \\
\hline 10,000 \& up & 1,476 & 9,029 & 6 & 668 & 4,880 & 7 \\
\hline Overall & 1,568 & 14,064 & 9 & 951 & 8,523 & 9 \\
\hline
\end{tabular}

Table 8 summarizes data relating population density, trips and miles traveled. The data reveal a tendency toward fewer person trips in areas with the highest and lowest densities, with some variation in between. The person miles traveled (PMT), however, declines as population density increases, suggesting fewer miles associated with each trip at higher densities.

Vehicle trips decrease steadily as population density increases. The vehicle miles traveled (VMT) associated with these trips also decreases. The exception occurs in areas where the population density is 10,000 or higher in which the average number of miles per trip increases slightly to 5.4 .

\section{Median Household Income/Poverty}

TABLE 9: BLOCK GROUP MEDIAN HOUSEHOLD INCOME BY AREA TYPE

\begin{tabular}{|c|c|c|c|c|c|c|}
\hline \multirow[t]{2}{*}{ Household Income } & \multicolumn{6}{|c|}{ Area Type } \\
\hline & Second City & Rural & Suburban & Town & Urban & All \\
\hline$\$ 0$ to $\$ 24,999$ & $32.6 \%$ & $28.2 \%$ & $0.9 \%$ & $16.6 \%$ & $28.2 \%$ & $19.7 \%$ \\
\hline$\$ 25,000$ to $\$ 34,999$ & $23.8 \%$ & $43.2 \%$ & $16.5 \%$ & $24.7 \%$ & $27.0 \%$ & $26.5 \%$ \\
\hline$\$ 35,000$ to $\$ 44,999$ & $16.9 \%$ & $22.4 \%$ & $21.8 \%$ & $21.1 \%$ & $19.7 \%$ & $20.6 \%$ \\
\hline$\$ 45,000$ to $\$ 54,999$ & $12.1 \%$ & $5.6 \%$ & $22.9 \%$ & $18.2 \%$ & $13.1 \%$ & $15.0 \%$ \\
\hline$\$ 55,000$ \& up & $14.6 \%$ & $0.6 \%$ & $37.9 \%$ & $19.4 \%$ & $12.0 \%$ & $18.3 \%$ \\
\hline Total & $100.0 \%$ & $100.0 \%$ & $100.0 \%$ & $100.0 \%$ & $100.0 \%$ & $100.0 \%$ \\
\hline
\end{tabular}


FIGURE 3: MEDIAN HOUSEHOLD INCOME BY AREA TYPE

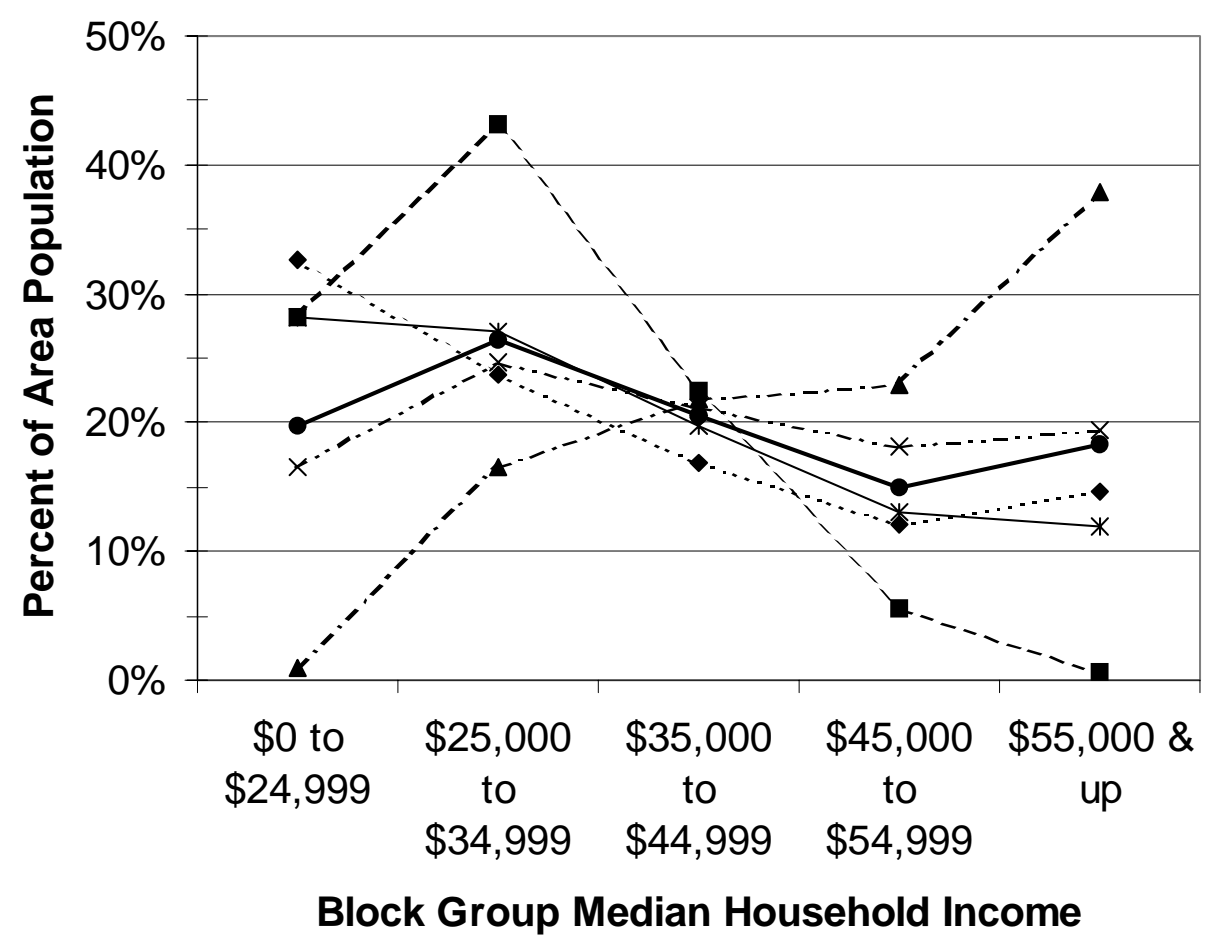

.... Second City $--\mathbf{m}--$ Rural $-\cdot \_--$Suburban $-\cdot \cdots \star \cdots-$ Town $\longrightarrow$ * Urban $\longrightarrow$ All

As summarized in Table 9, wealthy households dominate in the suburbs, middle income households prevail in rural areas, and households in the lowest income category are most common in second cities and in urban and rural areas. Suburban areas have the highest percentage of households with a median income of $\$ 55,000$ and higher; these households comprise $37.9 \%$ of all households in suburban areas, twice the overall percentage for this income category. Rural areas have the lowest percentage share of households in the two highest income categories; households with incomes of $\$ 45,000$ and higher comprise only $6.1 \%$ of all households. The middle income categories prevail in rural areas where households with median incomes of $\$ 25,000$ to $\$ 44,999$ comprise $65.6 \%$ of all households.

In second cities, the percentage of low-income residents (32.6\%) is greater than the percentage of low-income residents in both rural areas $(28.2 \%)$ and urban areas $(28.2 \%)$. This indicates a growing trend for the poor who have traditionally resided in inner cities to follow the waves of people leaving central cities for outlying areas. This movement of low-income groups will create significant challenges for meeting transportation needs: second cities must plan for an influx of low-income residents who cannot afford private vehicles and must depend on public transportation for mobility. Because they have been recently developed, second cities do not have the public transportation infrastructure which urban areas have developed over decades. Transit accessibility will become increasingly important. 
TABLE 10: TRANSIT AVAILABILITY BY BLOCK GROUP MEDIAN HOUSEHOLD INCOME

\begin{tabular}{|c|c|c|c|}
\hline \multicolumn{4}{|c|}{ Transit Availability } \\
\hline$\frac{\text { Household }}{\text { Income }}$ & $\frac{\text { Bus Service }}{\text { Available }}$ & No Bus & Total \\
\hline$\overline{\$ 0 \text { to } \$ 24,999}$ & $59.4 \%$ & $40.6 \%$ & $100.0 \%$ \\
\hline$\$ 25,000$ to $\$ 34,999$ & $56.3 \%$ & $43.7 \%$ & $100.0 \%$ \\
\hline$\$ 35,000$ to $\$ 44,999$ & $64.1 \%$ & $35.9 \%$ & $100.0 \%$ \\
\hline$\$ 45,000$ to $\$ 54,999$ & $70.6 \%$ & $29.4 \%$ & $100.0 \%$ \\
\hline$\$ 55,000 \&$ up & $72.8 \%$ & $27.2 \%$ & $100.0 \%$ \\
\hline Total & $63.4 \%$ & $36.6 \%$ & $100.0 \%$ \\
\hline
\end{tabular}

As shown in Table 10, transit availability is positively related to median household income: as household income increases, transit availability also increases. This finding merits attention because transit usage is typically associated with the lowest income categories; however, these data indicate that only $60 \%$ of households with incomes of $\$ 0$ to $\$ 24,999$ have access to bus service. Because low income households are more commonly dependent on transit for mobility, the lack of available public transportation has social and economic implications.

TABLE 11: DISTANCE TO TRANSIT FROM HOUSEHOLD BY POVERTY STATUS

\begin{tabular}{|c|c|c|c|c|c|}
\hline \multirow[b]{2}{*}{ Distance to Transit } & \multicolumn{5}{|c|}{ Percent of Block Group Living in Poverty } \\
\hline & Less than $4 \%$ & $4 \%$ to $6 \%$ & 7 to $12 \%$ & $13 \%$ \& up & All \\
\hline Less than .1 mile & $28.6 \%$ & $31.6 \%$ & $36.5 \%$ & $47.6 \%$ & $36.0 \%$ \\
\hline .1 to .24 mile & $12.6 \%$ & $13.5 \%$ & $14.4 \%$ & $17.0 \%$ & $14.3 \%$ \\
\hline .25 to .49 mile & $10.2 \%$ & $11.4 \%$ & $11.0 \%$ & $10.9 \%$ & $10.8 \%$ \\
\hline .5 to .99 mile & $32.0 \%$ & $27.2 \%$ & $24.9 \%$ & $15.7 \%$ & $25.1 \%$ \\
\hline 1 Mile \& up & $16.7 \%$ & $16.3 \%$ & $13.2 \%$ & $8.9 \%$ & $13.8 \%$ \\
\hline Total & $100.0 \%$ & $100.0 \%$ & $100.0 \%$ & $100.0 \%$ & $100.0 \%$ \\
\hline
\end{tabular}

Table 11 reveals a tendency for transit accessibility to be greatest for those areas in which the percent of the population living in poverty is the greatest. In those areas where more than $13 \%$ of block groups live in poverty, $47.6 \%$ live less than .1 mile from transit. As distance from transit increases the block groups with more than $13 \%$ of its residents living in poverty decreases. However, results also indicate that there are areas having significant numbers living below poverty that are located from .5 to over a mile from transit. For example, $24.9 \%$ of block groups that have 7 to $12 \%$ living in poverty are located from .5 to .99 of a mile from transit. 


\section{TABLE 12: ANNUALIZED INDIVIDUAL TRAVEL BEHAVIOR BY HOUSEHOLD INCOME}

\begin{tabular}{|c|c|c|c|c|c|c|}
\hline \multirow[b]{2}{*}{$\begin{array}{l}\text { Block Group Median } \\
\text { Household Income }\end{array}$} & \multicolumn{6}{|c|}{ Annualized Individual Travel Behavior } \\
\hline & $\frac{\text { Person }}{\text { Trips }}$ & $\frac{\text { Person Miles }}{\text { Traveled (PMT) }}$ & $\frac{\text { Person Miles }}{\text { per Trip }}$ & $\frac{\text { Vehicle }}{\text { Trips }}$ & $\begin{array}{l}\text { Vehicle Miles } \\
\text { Traveled (VMT) }\end{array}$ & $\frac{\text { Vehicle Miles }}{\text { per Trip }}$ \\
\hline$\$ 0$ to $\$ 24,999$ & $\overline{1,482}$ & 12,173 & 8 & 821 & 7,026 & 9 \\
\hline$\$ 25,000$ to $\$ 34,999$ & 1,585 & 13,594 & 9 & 968 & 8,526 & 9 \\
\hline$\$ 35,000$ to $\$ 44,999$ & 1,567 & 14,761 & 9 & 984 & 9,161 & $\varsigma$ \\
\hline$\$ 45,000$ to $\$ 54,999$ & 1,592 & 15,040 & 9 & 988 & 8,896 & 9 \\
\hline$\$ 55,000$ \& up & 1,619 & 15,199 & 9 & 1,001 & 9,109 & 9 \\
\hline Overall & 1,568 & 14,064 & 9 & 951 & 8,523 & \\
\hline
\end{tabular}

As shown in Table 12, both trips and miles of travel are positively associated with income. Person trips and PMT generally increase as household income increases. The average number of miles associated with each trip also increases. Vehicle trips generally increase as household income increases. The VMT associated with these trips also increases.

\section{Race and Hispanic Origin}

TABLE 13: RACE BY AREA TYPE

\begin{tabular}{|c|c|c|c|c|c|c|}
\hline \multirow[b]{2}{*}{ Race } & \multicolumn{6}{|c|}{ Area Type } \\
\hline & Second City & $\underline{\text { Rural }}$ & Suburban & Town & Urban & All \\
\hline White & $73.5 \%$ & $88.9 \%$ & $80.4 \%$ & $\overline{86.5} \%$ & $53.7 \%$ & $\overline{78.2} \%$ \\
\hline $\begin{array}{l}\text { African- } \\
\text { American }\end{array}$ & $16.2 \%$ & $6.5 \%$ & $9.9 \%$ & $7.1 \%$ & $28.3 \%$ & $12.5 \%$ \\
\hline Asian & $1.9 \%$ & $0.4 \%$ & $3.6 \%$ & $1.1 \%$ & $4.5 \%$ & $2.2 \%$ \\
\hline Other & $8.4 \%$ & $4.2 \%$ & $6.1 \%$ & $5.3 \%$ & $13.5 \%$ & $7.1 \%$ \\
\hline Total & $100.0 \%$ & $100.0 \%$ & $100.0 \%$ & $100.0 \%$ & $100.0 \%$ & $100.0 \%$ \\
\hline
\end{tabular}

Racial mix varies significantly in different area types. Whites form the majority in all types of areas, but they dominate most in rural areas (88.9\%), where all other racial groups combined account for only $11.1 \%$ of the population. African-Americans have the most significant presence in urban areas, with one African-American person for every two white persons.

African-Americans also have a significant, albeit greatly diminished, presence in second cities. Although second cities have certain population characteristics similar to urban areas, second cities have far less diversity in terms of racial mix when compared to urban areas. 


\section{TABLE 14: TRANSIT AVAILABILITY BY RACE OR HISPANIC ORIGIN}

\begin{tabular}{|c|c|c|c|}
\hline \multirow[b]{2}{*}{$\underline{\text { Race/Hispanic Origin }}$} & \multicolumn{2}{|c|}{ Transit Availability } & \multirow[b]{2}{*}{ Total } \\
\hline & $\frac{\text { Bus Service }}{\text { Available }}$ & No Bus & \\
\hline White & $59.3 \%$ & $40.7 \%$ & $100.0 \%$ \\
\hline African-American & $80.0 \%$ & $20.0 \%$ & $100.0 \%$ \\
\hline Asian & $86.5 \%$ & $13.5 \%$ & $100.0 \%$ \\
\hline Other & $75.8 \%$ & $24.2 \%$ & $100.0 \%$ \\
\hline All & $63.3 \%$ & $36.7 \%$ & $100.0 \%$ \\
\hline Hispanic & $76.8 \%$ & $23.2 \%$ & $100.0 \%$ \\
\hline Non-Hispanic & $62.2 \%$ & $37.8 \%$ & $100.0 \%$ \\
\hline All & $63.4 \%$ & $36.6 \%$ & $100.0 \%$ \\
\hline
\end{tabular}

Table 14 shows that both African-Americans and Asians have higher than average transit availability, while the availability of transit for whites is below average. Transit is also available to a greater than average percentage of Hispanics.

TABLE 15: MODE OF TRANSPORTATION BY RACE OR HISPANIC ORIGIN

\begin{tabular}{|c|c|c|c|c|c|c|c|c|}
\hline \multirow[b]{2}{*}{ Mode } & \multicolumn{5}{|c|}{ Race of Household Reference Person } & \multicolumn{3}{|c|}{ Reference Hispanic Status } \\
\hline & White & $\begin{array}{l}\text { African- } \\
\text { American }\end{array}$ & $\underline{\text { Asian }}$ & Other & All & Hispanic & $\begin{array}{l}\text { Non- } \\
\text { Hispanic }\end{array}$ & All \\
\hline Private Vehicle & $91.3 \%$ & $79.0 \%$ & $86.1 \%$ & $84.8 \%$ & $89.4 \%$ & $84.8 \%$ & $89.8 \%$ & $89.3 \%$ \\
\hline Public Transit & $3.0 \%$ & $10.1 \%$ & $4.5 \%$ & $5.2 \%$ & $4.0 \%$ & $5.6 \%$ & $3.9 \%$ & $4.0 \%$ \\
\hline Taxi & $0.1 \%$ & $0.5 \%$ & $0.1 \%$ & $0.3 \%$ & $0.2 \%$ & $0.2 \%$ & $0.2 \%$ & $0.2 \%$ \\
\hline Bicycle/Walk & $5.5 \%$ & $10.4 \%$ & $9.2 \%$ & $9.7 \%$ & $6.4 \%$ & $9.4 \%$ & $6.1 \%$ & $6.5 \%$ \\
\hline Total & $100.0 \%$ & $100.0 \%$ & $100.0 \%$ & $100.0 \%$ & $100.0 \%$ & $100.0 \%$ & $100.0 \%$ & $100.0 \%$ \\
\hline
\end{tabular}

Table 15 shows that the private vehicle is the dominant mode of transportation for all groups. Whites rely on private vehicles more than any other group and less on public transit than these groups. African-Americans depend on private vehicles less than all other groups and more on public transit and bicycling and walking. Hispanics use private vehicles less than Non-Hispanics and less than the average. As with African-Americans, they are more likely to use public transit and bicycling and walking. 
Age

TABLE 16: AGE BY AREA TYPE

\begin{tabular}{|c|c|c|c|c|c|c|}
\hline \multirow[b]{2}{*}{ Age Group } & \multicolumn{6}{|c|}{ Area Type } \\
\hline & Second City & Rural & Suburban & Town & Urban & All \\
\hline 5 to 15 & $16.0 \%$ & $19.2 \%$ & $17.9 \%$ & $19.3 \%$ & $16.0 \%$ & $17.8 \%$ \\
\hline 16 to 19 & $5.6 \%$ & $6.4 \%$ & $5.8 \%$ & $6.0 \%$ & $5.3 \%$ & $5.8 \%$ \\
\hline 20 to 29 & $18.0 \%$ & $11.4 \%$ & $14.5 \%$ & $12.9 \%$ & $17.5 \%$ & $14.6 \%$ \\
\hline 30 to 39 & $17.4 \%$ & $18.1 \%$ & $19.7 \%$ & $19.4 \%$ & $21.0 \%$ & $19.1 \%$ \\
\hline 40 to 49 & $14.8 \%$ & $15.5 \%$ & $16.6 \%$ & $16.3 \%$ & $14.1 \%$ & $15.6 \%$ \\
\hline 50 to 59 & $9.0 \%$ & $11.1 \%$ & $10.2 \%$ & $9.9 \%$ & $9.0 \%$ & $9.9 \%$ \\
\hline 60 to 69 & $8.9 \%$ & $9.0 \%$ & $8.0 \%$ & $8.2 \%$ & $8.3 \%$ & $8.0 \%$ \\
\hline $70 \&$ up & $10.4 \%$ & $9.3 \%$ & $7.2 \%$ & $8.1 \%$ & $8.7 \%$ & $8.6 \%$ \\
\hline Total & $100.0 \%$ & $100.0 \%$ & $100.0 \%$ & $100.0 \%$ & $100.0 \%$ & $100.0 \%$ \\
\hline
\end{tabular}

TABLE 17: FAMILY LIFE CYCLE BY AREA TYPE

\begin{tabular}{|c|c|c|c|c|c|c|}
\hline \multirow[b]{2}{*}{ Family Life Cycle } & \multicolumn{6}{|c|}{ Area Type } \\
\hline & $\frac{\text { Second }}{\text { City }}$ & $\underline{\text { Rural }}$ & Suburban & Town & Urban & All \\
\hline Single Adult, No Children & $20.1 \%$ & $12.5 \%$ & $16.2 \%$ & $13.6 \%$ & $24.6 \%$ & $17.0 \%$ \\
\hline Two or More Adults, No Children & $23.4 \%$ & $23.4 \%$ & $24.6 \%$ & $23.2 \%$ & $23.3 \%$ & $23.6 \%$ \\
\hline Single Adult, Youngest Child 0-5 & $1.8 \%$ & $1.0 \%$ & $1.0 \%$ & $1.8 \%$ & $2.8 \%$ & $1.6 \%$ \\
\hline Two or More Adults, Youngest Child 0-5 & $13.1 \%$ & $14.0 \%$ & $16.3 \%$ & $16.5 \%$ & $13.4 \%$ & $14.8 \%$ \\
\hline Single Adult, Youngest Child 6-15 & $2.8 \%$ & $2.5 \%$ & $2.5 \%$ & $2.1 \%$ & $3.2 \%$ & $2.6 \%$ \\
\hline Two or More Adults, Youngest Child 6-15 & $12.1 \%$ & $17.6 \%$ & $15.5 \%$ & $17.0 \%$ & $10.6 \%$ & $14.8 \%$ \\
\hline Single Adult, Youngest Child 16-21 & $1.2 \%$ & $0.8 \%$ & $1.1 \%$ & $1.2 \%$ & $1.1 \%$ & $1.1 \%$ \\
\hline Two or More Adults, Youngest Child 16-21 & $3.4 \%$ & $5.3 \%$ & $5.0 \%$ & $4.9 \%$ & $2.9 \%$ & $4.4 \%$ \\
\hline Single Adult Retired & $9.9 \%$ & $8.9 \%$ & $6.1 \%$ & $7.1 \%$ & $8.2 \%$ & $7.9 \%$ \\
\hline Two or More Adults Retired & $12.2 \%$ & $13.8 \%$ & $11.7 \%$ & $12.6 \%$ & $9.9 \%$ & $12.1 \%$ \\
\hline Total & $100.0 \%$ & $100.0 \%$ & $100.0 \%$ & $100.0 \%$ & $100.0 \%$ & $100.0 \%$ \\
\hline
\end{tabular}

The 1995 NPTS contains information on age and life cycle patterns, see Tables 16 and 17. As shown in Table 17, cities attract young adults, both single and married, who have no children. These findings indicate a preference by these groups to locate in more densely populated urban settings. Rural areas and towns, in contrast, have lower than average percentages of single, childless adults. Towns and rural and suburban areas are more likely than average to be populated by households with two or more adults and school-age children, indicating a possible educational component in choice of residential location. Rural areas attract a lower percentage of young adults (20-29 years old) than urban areas and second cities. 
TABLE 18: ONE-WAY WORK TRIP BY AGE AND GENDER

\begin{tabular}{|c|c|c|c|c|c|c|c|c|}
\hline \multirow[b]{3}{*}{ Age Group } & \multicolumn{4}{|c|}{ Distance to Work (Miles) } & \multicolumn{4}{|c|}{ Time to Work (Minutes) } \\
\hline & \multicolumn{2}{|c|}{$\underline{\text { Male }}$} & \multicolumn{2}{|c|}{ Female } & \multicolumn{2}{|c|}{ Male } & \multicolumn{2}{|c|}{ Female } \\
\hline & $\frac{\text { Mea }}{n}$ & $\frac{\text { Media }}{n}$ & $\frac{\text { Mea }}{n}$ & $\frac{\text { Media }}{n}$ & $\frac{\text { Mea }}{n}$ & $\frac{\text { Media }}{n}$ & $\frac{\text { Mea }}{n}$ & $\frac{\text { Media }}{n}$ \\
\hline 16 to 19 & 7 & 5 & 7 & 4 & 14 & 10 & 15 & 10 \\
\hline 20 to 29 & 13 & 8 & 12 & 8 & 22 & 15 & 21 & 15 \\
\hline 30 to 39 & 15 & 10 & 12 & 8 & 25 & 20 & 22 & 18 \\
\hline 40 to 49 & 16 & 10 & 11 & 8 & 25 & 20 & 21 & 15 \\
\hline 50 to 59 & 15 & 10 & 10 & 7 & 25 & 20 & 20 & 15 \\
\hline 60 to 69 & 14 & 8 & 7 & 5 & 25 & 15 & 16 & 15 \\
\hline $70 \&$ up & 8 & 5 & 7 & 4 & 20 & 15 & 16 & 13 \\
\hline
\end{tabular}

Table 18 shows a tendency for younger workers to have shorter work trip distances and trip times. This is true regardless of gender. The trip distance of males increases until the age of 49 when it begins to decrease. However, work trip times for males reaches a peak at age 30 and levels off through age 69, indicating a stable trip time independent of distance. Females have shorter work trip distances and travel times across all age groups. Mean trip distance peaks between the ages of 20 and 40 and begins to decline thereafter. However, work trip times exhibit a slight peak in the 30 to 39 age group category. Not surprisingly, work trip distance and trip times decline significantly for workers in the 70 and up age group category.

TABLE 19: TRANSIT AVAILABILITY BY FAMILY LIFE CYCLE

\begin{tabular}{|c|c|c|c|}
\hline \multirow[b]{2}{*}{ Family Life Cycle } & \multicolumn{2}{|c|}{ Transit Availability } & \multirow[b]{2}{*}{$\underline{\text { Total }}$} \\
\hline & $\frac{\text { Bus Service }}{\text { Available }}$ & No Bus & \\
\hline Single Adult, No Children & $71.7 \%$ & $28.3 \%$ & $100.0 \%$ \\
\hline Two or More Adults, No Children & $62.5 \%$ & $37.5 \%$ & $100.0 \%$ \\
\hline Single Adult, Youngest Child 0-5 & $67.7 \%$ & $32.3 \%$ & $100.0 \%$ \\
\hline Two or More Adults, Youngest Child 0-5 & $64.9 \%$ & $35.1 \%$ & $100.0 \%$ \\
\hline Single Adult, Youngest Child 6-15 & $66.0 \%$ & $34.0 \%$ & $100.0 \%$ \\
\hline Two or More Adults, Youngest Child 6-15 & $58.4 \%$ & $41.6 \%$ & $100.0 \%$ \\
\hline Single Adult, Youngest Child 16-21 & $69.4 \%$ & $30.6 \%$ & $100.0 \%$ \\
\hline Two or More Adults, Youngest Child 16-21 & $56.8 \%$ & $43.2 \%$ & $100.0 \%$ \\
\hline Single Adult Retired & $64.2 \%$ & $35.8 \%$ & $100.0 \%$ \\
\hline Two or More Adults Retired & $57.5 \%$ & $42.5 \%$ & $100.0 \%$ \\
\hline All & $63.3 \%$ & $36.7 \%$ & $100.0 \%$ \\
\hline
\end{tabular}

Table 19 shows the relationship between family life cycle and availability of transit at the residence. For all life cycle categories, transit service is available to over $55 \%$ of households, 
compared to the overall average of $63.3 \%$. The data indicate that households with a single adult are more likely to live where transit is available. This tendency is greatest for single adults with no children (71.7\%) and holds true for all stages of life. In contrast, households with two or more adults are less likely to live where transit is available, indicating less need or preference to use transit. Households with two or more adults and young children are an exception to this general tendency, with $64.9 \%$ reporting transit availability at the residence. According to these data, transit availability at the residence is closely associated with family life cycle.

TABLE 20: DISTANCE TO TRANSIT BY FAMILY LIFE CYCLE

\begin{tabular}{|c|c|c|c|c|c|c|}
\hline \multirow[b]{2}{*}{ Family Life Cycle } & \multicolumn{6}{|c|}{ Distance to Transit from Household (Miles) } \\
\hline & $\begin{array}{l}\text { Less } \\
\text { than .1 }\end{array}$ & $\frac{.1 \text { to }}{.24}$ & $\frac{.25 \text { to }}{.49}$ & $\frac{.5 \text { to }}{.99}$ & $\frac{1 \text { Mile }}{\& \text { up }}$ & All \\
\hline Single Adult, No Children & $24.4 \%$ & $19.9 \%$ & $18.6 \%$ & $16.1 \%$ & $12.2 \%$ & $19.4 \%$ \\
\hline Two or More Adults, No Children & $21.6 \%$ & $22.6 \%$ & $23.3 \%$ & $25.5 \%$ & $23.7 \%$ & $23.2 \%$ \\
\hline Single Adult, Youngest Child 0-5 & $2.6 \%$ & $1.4 \%$ & $1.3 \%$ & $1.1 \%$ & $1.3 \%$ & $1.8 \%$ \\
\hline Two or More Adults, Youngest Child 0-5 & $13.3 \%$ & $13.5 \%$ & $12.8 \%$ & $16.7 \%$ & $20.1 \%$ & $15.1 \%$ \\
\hline Single Adult, Youngest Child 6-15 & $3.4 \%$ & $2.9 \%$ & $2.4 \%$ & $2.6 \%$ & $1.6 \%$ & $2.8 \%$ \\
\hline Two or More Adults, Youngest Child 6-15 & $11.5 \%$ & $12.7 \%$ & $11.7 \%$ & $15.4 \%$ & $19.7 \%$ & $13.8 \%$ \\
\hline Single Adult, Youngest Child 16-21 & $1.3 \%$ & $1.0 \%$ & $1.1 \%$ & $1.2 \%$ & $1.2 \%$ & $1.2 \%$ \\
\hline Two or More Adults, Youngest Child 16-21 & $3.2 \%$ & $3.7 \%$ & $3.6 \%$ & $4.7 \%$ & $4.9 \%$ & $3.9 \%$ \\
\hline Single Adult Retired & $9.3 \%$ & $9.8 \%$ & $10.3 \%$ & $5.6 \%$ & $4.6 \%$ & $7.9 \%$ \\
\hline Two or More Adults Retired & $9.5 \%$ & $12.6 \%$ & $14.8 \%$ & $11.1 \%$ & $10.6 \%$ & $11.1 \%$ \\
\hline Total & $100.0 \%$ & $100.0 \%$ & $100.0 \%$ & $100.0 \%$ & $100.0 \%$ & $100.0 \%$ \\
\hline
\end{tabular}

As shown in Table 20, transit is most closely located near households with no children and a working-age adult (24.4\%). Households with two or more adults and no children are evenly distributed across all transit access categories, with the highest percentage occurring between 5 and .99 miles $(25.5 \%)$. Families with two or more adults and children under 16 are more likely to live one-half mile from transit or more, indicating less dependence on transit than other family types. Single retirees are more likely than average to live within .5 mile from transit, while families with two or more retired adults are more likely to live from .1 to .99 miles from transit, also indicating less dependence on transit than their single counterparts. 


\section{Education}

\begin{tabular}{|c|c|c|c|}
\hline \multirow[b]{2}{*}{$\begin{array}{c}\text { Education of Household } \\
\text { Reference Person }\end{array}$} & \multicolumn{2}{|c|}{ Transit Availability } & \multirow[b]{2}{*}{ Total } \\
\hline & $\frac{\text { Bus Service }}{\text { Available }}$ & No Bus & \\
\hline Less Than HS Graduate & $54.0 \%$ & $46.0 \%$ & $100.0 \%$ \\
\hline High School Graduate & $58.4 \%$ & $41.6 \%$ & $100.0 \%$ \\
\hline Some College, No Degree & $66.1 \%$ & $33.9 \%$ & $100.0 \%$ \\
\hline Associate Degree & $62.7 \%$ & $37.3 \%$ & $100.0 \%$ \\
\hline Bachelors Degree & $70.0 \%$ & $30.0 \%$ & $100.0 \%$ \\
\hline Some Grad/Prof School & $68.5 \%$ & $31.5 \%$ & $100.0 \%$ \\
\hline Grad/Prof School Degree & $71.2 \%$ & $28.8 \%$ & $100.0 \%$ \\
\hline All & $63.1 \%$ & $36.9 \%$ & $100.0 \%$ \\
\hline
\end{tabular}

As shown in Table 21, transit availability generally increases as education increases, indicating a positive relationship between the two. On average, transit is available to $63.1 \%$ of households. This compares to $54.0 \%$ for households in which the reference person has less than a high school education and $58.4 \%$ for households in which the reference person has graduated from high school. The percentage for households in which the reference person has attended college exceeds the average, with the exception of the associate degree category. The positive relationship between transit availability and education does not hold true for the category of persons who have some graduate or professional school. The percentage for this category is $68.5 \%$, a decrease of $1.5 \%$ compared to households in which the reference person has a bachelors degree $(70.0 \%)$.

\section{Measures for Places}

\section{Area Type}

The 1995 NPTS bases urban/rural coding on population densities at a location and in relation to neighboring locations (see Key Terms and Definitions for an explanation) .

TABLE 22: DRIVERS PER ADULT BY AREA TYPE

\begin{tabular}{|c|c|c|c|c|c|c|}
\hline \multirow[b]{2}{*}{ Drivers per Adult } & \multicolumn{6}{|c|}{ Area Type } \\
\hline & Second City & Rural & Suburban & Town & Urban & Overall \\
\hline Less than One & $16.7 \%$ & $\overline{11.9 \%}$ & $10.7 \%$ & $\overline{11.5 \%}$ & $32.2 \%$ & $15.8 \%$ \\
\hline One Driver & $80.0 \%$ & $82.0 \%$ & $84.6 \%$ & $83.2 \%$ & $66.2 \%$ & $79.9 \%$ \\
\hline More than One & $3.3 \%$ & $6.1 \%$ & $4.7 \%$ & $5.3 \%$ & $1.6 \%$ & $4.3 \%$ \\
\hline Total & $100.0 \%$ & $100.0 \%$ & $100.0 \%$ & $100.0 \%$ & $100.0 \%$ & $100.0 \%$ \\
\hline
\end{tabular}


The majority of all adults in America drive. This ratio of drivers to adults varies, however, with area type. In towns, second cities, suburban, and rural areas, over $80 \%$ of the population has a ratio of one driver for every adult.

Rural areas have the largest percentage of ratios above one driver per adult. The NPTS defines adults as persons eighteen years of age or older; whereas, many states allow people to earn driver's licenses at sixteen years of age. Sixteen and seventeen year olds account for ratios above one driver per adult. Rural areas, therefore, have the largest percentage of their young people driving. Rural residents require private transportation for much of daily living, and young people need to attain driving privileges for mobility.

Urban areas have the lowest ratio of drivers per adult. The high percentage $(32.2 \%)$ of urban populations having less than one driver per adult indicates less dependence on private vehicles. Urban areas offer more options for public transit, and many destinations can be accessed by walking or bicycling.

TABLE 23: VEHICLES PER ADULT BY AREA TYPE

\begin{tabular}{rrrrrrrr} 
& & \multicolumn{6}{c}{ Area Type } \\
Vehicles per Adult & Second City & Rural & Suburban & Town & Urban & \multicolumn{1}{c}{ Total } \\
\cline { 2 - 5 } & $27.1 \%$ & $18.4 \%$ & $20.1 \%$ & $18.3 \%$ & $47.0 \%$ & $25.1 \%$ \\
Less than One & $61.6 \%$ & $56.1 \%$ & $65.6 \%$ & $62.4 \%$ & $46.1 \%$ & $59.1 \%$ \\
One Vehicle & $11.3 \%$ & $25.4 \%$ & $14.3 \%$ & $19.4 \%$ & $6.9 \%$ & $15.8 \%$ \\
More than One & $100.0 \%$ & $100.0 \%$ & $100.0 \%$ & $100.0 \%$ & $100.0 \%$ & $100.0 \%$
\end{tabular}

Vehicle ownership per adults follows patterns similar to the patterns of drivers per adult. In rural areas, over one quarter of the adults have more than one vehicle, but in urban areas, nearly half of the residents have less than one vehicle for each adult. Over one quarter of the residents of second cities also have less than one vehicle for each adult. In second cities, towns, and suburban areas, over $60 \%$ of the population have exactly one vehicle per adult.

The land use of an area can affect the number of vehicles per adult: close access to destinations and plentiful transportation facilities may induce less vehicle ownership in urban areas. The number of vehicles in an area can also affect land use. High levels of vehicle ownership require parking structures, lots, and facilities to accommodate the vehicles. Rural areas have the space necessary to support high vehicle ownership; whereas, land values in urban areas make vehicle ownership expensive. 
TABLE 24: WORK LOCATION BY AREA TYPE

\begin{tabular}{|c|c|c|c|c|c|c|}
\hline \multirow[b]{2}{*}{ Work Location } & \multicolumn{6}{|c|}{ Area Type } \\
\hline & Second City & Rural & Suburban & Town & Urban & $\underline{\text { All }}$ \\
\hline Work from Home & $5.2 \%$ & $8.2 \%$ & $5.3 \%$ & $5.8 \%$ & $5.0 \%$ & $5.9 \%$ \\
\hline No Fixed Work Place & $2.0 \%$ & $2.6 \%$ & $2.0 \%$ & $1.9 \%$ & $2.6 \%$ & $2.2 \%$ \\
\hline Work at Work Location & $92.8 \%$ & $89.2 \%$ & $92.7 \%$ & $92.3 \%$ & $92.4 \%$ & $91.9 \%$ \\
\hline Total & $100.0 \%$ & $100.0 \%$ & $100.0 \%$ & $100.0 \%$ & $100.0 \%$ & $100.0 \%$ \\
\hline
\end{tabular}

As shown in Table 24, there is little variation in work location across area type. The percentage of people who work at the work location vastly exceeds the percentages of people who work at home and those who have no fixed work place. The distribution is very similar within the second city, suburban, town and urban categories. The percentage distribution within these categories hovers near the overall percentages for each category. Rural areas vary from this pattern, with more people working from home than average and fewer people working at the work location than average.

TABLE 25: ONE-WAY WORK TRIP BY AREA TYPE AND GENDER

\begin{tabular}{|c|c|c|c|c|c|c|c|c|}
\hline & \multicolumn{4}{|c|}{ Distance to Work (Miles) } & \multicolumn{4}{|c|}{ Time to Work (Minutes) } \\
\hline & \multicolumn{2}{|c|}{ Male } & \multicolumn{2}{|c|}{ Female } & \multicolumn{2}{|c|}{ Male } & \multicolumn{2}{|c|}{ Female } \\
\hline & Mea & Media & Mea & Media & Mea & Media & Mea & Media \\
\hline & $\overline{\mathbf{n}}$ & $\underline{\mathbf{n}}$ & $\overline{\mathbf{n}}$ & $\underline{n}$ & $\overline{\underline{n}}$ & $\underline{\mathbf{n}}$ & $\overline{\underline{n}}$ & $\underline{\mathbf{n}}$ \\
\hline Second City & 12 & 6 & 9 & 5 & 21 & 15 & 18 & 15 \\
\hline Rural & 18 & 12 & 13 & 10 & 24 & 20 & 20 & 15 \\
\hline Suburban & 14 & 10 & 11 & 8 & 24 & 20 & 21 & 17 \\
\hline Town & 16 & 10 & 12 & 7 & 24 & 20 & 19 & 15 \\
\hline Urban & 11 & 7 & 9 & 6 & 26 & 20 & 25 & 20 \\
\hline
\end{tabular}

The impact of area type on the distance to work by gender is reported in Table 25. Across all area types males generally travel greater distances to work and the mean travel time to work for males is also greater. The travel time to work for males and females is roughly equivalent in urban areas and their distance to work in urban areas is different by only two seconds. The distance to work for rural males is 18 miles and for females it is 13 miles. This is the greatest difference in distance to work across all area types. 
TABLE 26: TRANSIT AVAILABILITY BY AREA TYPE

\begin{tabular}{|c|c|c|c|}
\hline \multicolumn{4}{|c|}{ Transit Availability } \\
\hline Area Type & $\frac{\text { Bus Service }}{\text { Available }}$ & No Bus & Total \\
\hline Second City & $81.9 \%$ & $18.1 \%$ & $100.0 \%$ \\
\hline Rural & $14.3 \%$ & $85.7 \%$ & $100.0 \%$ \\
\hline Suburban & $87.4 \%$ & $12.6 \%$ & $100.0 \%$ \\
\hline Town & $37.6 \%$ & $62.4 \%$ & $100.0 \%$ \\
\hline Urban & $98.3 \%$ & $1.7 \%$ & $100.0 \%$ \\
\hline All & $63.4 \%$ & $36.6 \%$ & $100.0 \%$ \\
\hline
\end{tabular}

Table 26 summarizes the relationship between area type and transit availability. Urban areas have the highest percentage of available bus service (98.3\%), exceeding the overall average of $63.4 \%$ by nearly one-third. Suburban areas $(87.4 \%)$ and second city areas $(81.9 \%)$ also exceed the average by a large margin, indicating a tendency for these areas to have transit service available. Rural areas and towns both fall well-below the average with $14.3 \%$ and $37.6 \%$ service respectively.

TABLE 27: DISTANCE TO TRANSIT FROM THE HOUSEHOLD BY AREA TYPE

Area Type

\begin{tabular}{|c|c|c|c|c|c|c|}
\hline $\begin{array}{c}\text { Distance to Transit } \\
\text { from Household }\end{array}$ & Second City & Rural & Suburban & Town & Urban & All \\
\hline Less than .1 mile & $37.9 \%$ & $21.4 \%$ & $28.2 \%$ & $22.1 \%$ & $52.5 \%$ & $36.0 \%$ \\
\hline .1 to .24 mile & $16.0 \%$ & $1.6 \%$ & $13.4 \%$ & $6.3 \%$ & $19.6 \%$ & $14.3 \%$ \\
\hline .25 to .49 mile & $12.0 \%$ & $4.9 \%$ & $11.6 \%$ & $5.7 \%$ & $12.0 \%$ & $10.8 \%$ \\
\hline .5 to .99 mile & $24.3 \%$ & $18.3 \%$ & $34.4 \%$ & $27.5 \%$ & $14.3 \%$ & $25.1 \%$ \\
\hline 1 mile \& up & $9.7 \%$ & $53.8 \%$ & $12.3 \%$ & $38.4 \%$ & $1.6 \%$ & $13.8 \%$ \\
\hline Total & $100.0 \%$ & $100.0 \%$ & $100.0 \%$ & $100.0 \%$ & $100.0 \%$ & $100.0 \%$ \\
\hline
\end{tabular}


FIGURE 4: DISTANCE TO TRANSIT BY AREA TYPE

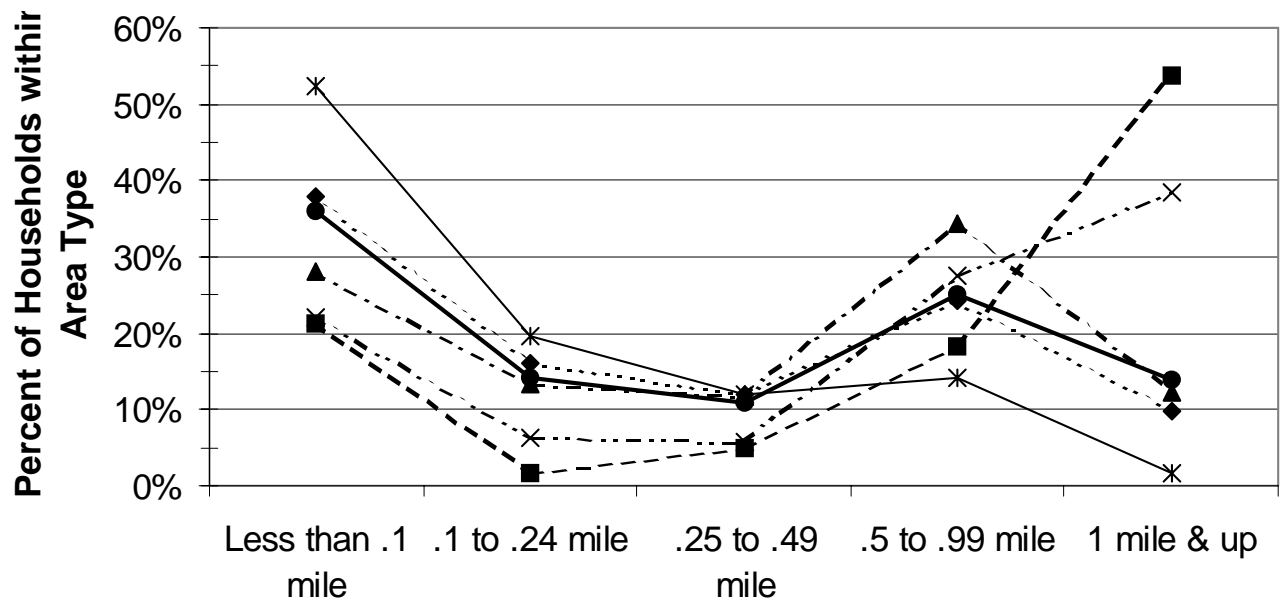

Distance to the Bus

\begin{tabular}{|c|c|c|}
\hline$\cdots \bullet$ Second City & --ם- - Rural & --.-Suburban \\
\hline$\cdots \times \cdots$ lown & * Urban & $\because$ All \\
\hline
\end{tabular}

Approximately $52.5 \%$ of persons living in urban areas are less than .1 mile form transit while this is true for only 21.45 of those living in rural areas. When the distance to transit increases to between .1 to .24 mile, $19.6 \%$ of urban area residents enjoy this high level of accessibility, but this is true for only $1.6 \%$ of those living in rural areas. Residents living in urban areas and in second cities enjoy greater accessibility to transit. Approximately $53.8 \%$ of residents of rural areas live at least one mile or further from transit as do $38.4 \%$ of persons living in towns. Only $1.6 \%$ of urban dwellers are one mile or more from transit. It is clear that residents of rural areas and towns are transit constrained.

\section{TABLE 28: AUTOMOBILE COMMUTING BY AREA TYPE}

\begin{tabular}{rrrrrrrr} 
& \multicolumn{6}{c}{ Area Type } \\
Commute Auto Usage & Second City & Rural & Suburban & Town & Urban & \multicolumn{1}{c}{ All } \\
So to Work by Auto & $80.1 \%$ & $67.3 \%$ & $83.0 \%$ & $75.5 \%$ & $69.4 \%$ & $75.9 \%$ \\
Do Not Go to Work by Auto & $19.9 \%$ & $32.7 \%$ & $17.0 \%$ & $24.5 \%$ & $30.6 \%$ & $24.1 \%$ \\
Total & $100.0 \%$ & $100.0 \%$ & $100.0 \%$ & $100.0 \%$ & $100.0 \%$ & $100.0 \%$
\end{tabular}

Table 28 shows that $75.9 \%$ of the population generally travels to work by auto. Second cities and suburban areas exceed this average with $80.1 \%$ and $83.0 \%$ of workers, respectively, using autos to travel to work. Rural and urban areas both fall below this average with $67.3 \%$ and 
$69.4 \%$ respectively. Work-related auto in towns falls at the average. These data indicate a greater dependence in second cities and suburban areas on auto use.

TABLE 29: ANNUALIZED INDIVIDUAL TRAVEL BEHAVIOR BY AREA TYPE

\begin{tabular}{|c|c|c|c|c|c|c|}
\hline \multirow[b]{2}{*}{ Area Type } & \multicolumn{6}{|c|}{ Annualized Individual Travel Behavior } \\
\hline & $\frac{\text { Person }}{\text { Trips }}$ & $\begin{array}{l}\text { Person Miles } \\
\text { Traveled (PMT) }\end{array}$ & $\frac{\text { Person Miles }}{\text { per Trip }}$ & $\frac{\text { Vehicle }}{\text { Trips }}$ & $\begin{array}{l}\text { Vehicle Miles } \\
\text { Traveled (VMT) }\end{array}$ & $\frac{\text { Vehicle Miles }}{\text { per Trip }}$ \\
\hline Second City & 1,609 & 13,445 & 8 & 988 & 7,982 & \\
\hline Rural & 1,549 & 16,833 & 11 & 961 & 10,432 & 11 \\
\hline Suburban & 1,595 & 13,790 & 9 & 1,009 & 8,431 & 8 \\
\hline Town & 1,579 & 15,350 & 10 & 1,002 & 9,563 & 10 \\
\hline Urban & 1,488 & 9,820 & 7 & 731 & 5,359 & 7 \\
\hline Overall & 1,568 & 14,064 & 9 & 951 & 8,523 & \\
\hline
\end{tabular}

With 1,549 person trips, rural residents have the second lowest number of overall trips, and they make the third highest number of vehicle trips at 961. Rural residents are tied much more to their personal vehicles than residents of other areas. They also cover the most distance at 16,833 person miles annually. Townsfolk cover the next highest distance at 15,350 person miles and 9,563 vehicle miles. Urban residents make the fewest number of trips and cover the shortest distance by far with 731 vehicle trips. Part of the reason why the number of trips remains so low for urban residents may have to do with issues of data collection: trips of less than one block or equal to one half mile may be undercounted.

\section{Residential Density}

Area types provide a broad look at the geographic landscape. Residential density allows a closer look at land uses where people live and also a link to measures of people. Residential and population densities reflect similar parameters: both indicate the extent of concentration where people live. Population density measures the number of people per square mile; residential density measures the number of living units per square mile. A proportional increase in residential density may correspond with a proportional increase in population density. The two measures diverge in instances where more or fewer people live in a household, compared to the average. Variables such as race or age may impact residential density. Some cultures, for instance, typically live in large households with extended families, while other cultures value independence from family. Similarly, large numbers of single-person households may appear where high concentrations of young adults live. 
TABLE 30: BLOCK GROUP RESIDENTIAL DENSITY BY AREA TYPE

\begin{tabular}{|c|c|c|c|c|c|c|}
\hline \multirow[b]{2}{*}{$\begin{array}{c}\text { Block Group Housing } \\
\text { Units per Mile }{ }^{2}\end{array}$} & \multicolumn{6}{|c|}{ Area Type } \\
\hline & Second City & Rural & Suburban & Town & Urban & All \\
\hline 0 to 99 & $2.7 \%$ & $81.3 \%$ & $1.4 \%$ & $26.8 \%$ & $0.4 \%$ & $23.0 \%$ \\
\hline 100 to 499 & $12.1 \%$ & $12.9 \%$ & $13.6 \%$ & $39.5 \%$ & $0.4 \%$ & $16.9 \%$ \\
\hline 500 to 1,499 & $32.7 \%$ & $4.3 \%$ & $36.2 \%$ & $22.6 \%$ & $6.1 \%$ & $21.6 \%$ \\
\hline 1,500 to 2,999 & $34.3 \%$ & $1.3 \%$ & $34.4 \%$ & $9.8 \%$ & $23.8 \%$ & $20.7 \%$ \\
\hline 3,000 \& up & $18.1 \%$ & $0.2 \%$ & $14.4 \%$ & $1.4 \%$ & $69.2 \%$ & $17.9 \%$ \\
\hline Total & $100.0 \%$ & $100.0 \%$ & $100.0 \%$ & $100.0 \%$ & $100.0 \%$ & $100.0 \%$ \\
\hline
\end{tabular}

Table 30 compares block group residential density to area type and reveals that urban and rural areas are at opposite ends of the spectrum with regard to residential density. Urban areas have the greatest percentage of dense residential areas and the lowest percentage of areas with sparse dwellings. Over $80 \%$ of rural areas have residential densities under 100 housing units per square mile. Second cities and suburban areas are comparable to each other with over $65 \%$ of block groups having between 500 and 3,000 housing units per square mile.

TABLE 31: MILES DRIVEN LAST YEAR BY RESIDENTIAL DENSITY AND GENDER

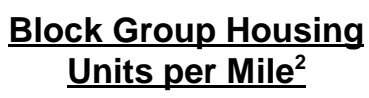
Units per Mile ${ }^{2}$

0 to 99
100 to 499
500 to 1,499
1,500 to 2,999
$3,000 \&$ up

\begin{tabular}{cccc}
\multicolumn{4}{c}{ Annual Miles Driven } \\
Male & \multicolumn{2}{c}{ Female } \\
Mean & Median & Mean & Median \\
& 14,000 & 10,637 & 9,500 \\
17,523 & 14,000 & 10,088 & 9,000 \\
15,382 & 12,000 & 8,987 & 8,000 \\
14,351 & 12,000 & 8,485 & 7,000 \\
12,360 & 10,000 & 7,387 & 5,000
\end{tabular}

The number of miles an individual drives annually consistently decreases as residential density increases. This trend appears in both mean and median measures of central tendency and holds true across gender. The genders diverge, however, in actual numbers of miles driven. In block groups with over 3,000 housing units per square mile, females drive 7,387 miles annually, which is 4,973 miles fewer per year than males do on average, a $60 \%$ difference. In areas with residential densities lower than 100 housing units per square mile, the large difference between the genders increases up to 7,134 miles annually on average, which is also a $60 \%$ difference. 
TABLE 32: ONE-WAY WORK TRIP BY RESIDENTIAL DENSITY AND GENDER

\begin{tabular}{|c|c|c|c|c|c|c|c|c|}
\hline \multirow{4}{*}{$\begin{array}{c}\text { Block Group Housing } \\
\underline{\text { Units per Mile }}\end{array}$} & \multicolumn{4}{|c|}{ Distance to Work (Miles) } & \multicolumn{4}{|c|}{ Time to Work (Minutes) } \\
\hline & \multicolumn{2}{|c|}{ Male } & \multicolumn{2}{|c|}{ Female } & \multicolumn{2}{|c|}{ Male } & \multicolumn{2}{|c|}{ Female } \\
\hline & Mea & Media & Mea & Media & Mea & Media & Mea & Media \\
\hline & $\underline{\mathbf{n}}$ & $\underline{\mathbf{n}}$ & $\underline{\mathbf{n}}$ & $\underline{\mathbf{n}}$ & $\underline{\mathbf{n}}$ & $\underline{\mathbf{n}}$ & $\underline{\mathbf{n}}$ & $\underline{\mathbf{n}}$ \\
\hline 0 to 99 & 17 & 12 & 13 & 10 & 24 & 20 & 20 & 15 \\
\hline 100 to 499 & 17 & 10 & 12 & 8 & 25 & 20 & 20 & 15 \\
\hline 500 to 1,499 & 14 & 9 & 11 & 7 & 22 & 18 & 20 & 15 \\
\hline 1,500 to 2,999 & 13 & 8 & 10 & 6 & 23 & 18 & 20 & 15 \\
\hline $3,000 \&$ up & 11 & 7 & 9 & 6 & 24 & 20 & 24 & 20 \\
\hline
\end{tabular}

For those block groups with 0-99 units per mile, men drive 17 miles while females drive an average of 13 miles one-way for the work trip (Table 32). At the very highest density 3,000 and up males drive 11 miles while females drive 9 miles. The statistics for the time to work corresponds to the pattern observed for distance traveled with males generally traveling greater distances and having correspondingly longer travel times. Males drive for approximately 24 minutes and females for 20 minutes at the lowest density block group and 24 minutes and 24 minutes respectively in the densest block group levels of 3,000 or more housing units. The distance to work decreases for both males and females as housing unit density increases. This is not true for travel time where males living in block groups with 0 to 99 units travel 24 minutes and males living in block groups with more than 3,000 units per mile also travel 24 minutes on average. For females, travel time to work is 20 minutes in low residential density areas and reverses the trend and increases to 24 minutes as density increases. As housing density increases distance to work decreases for males and females. However, as density increases we do not see a decrease in travel time for males or females. Travel time to work for females is constant at 20 minutes except for an increase in travel time for women living in the most densely populated block groups. There are many possible explanations including congestion associated with densely populated areas as well as the mode of travel or the time of day when the trip occurs.

TABLE 33: TRANSIT AVAILABILITY BY RESIDENTIAL DENSITY

\begin{tabular}{|c|c|c|c|}
\hline \multirow{2}{*}{$\begin{array}{c}\begin{array}{c}\text { Block Group } \\
\text { Residential Density } \\
\text { (Housing Units/ Mile })\end{array} \\
\end{array}$} & \multicolumn{3}{|c|}{ Transit Availability } \\
\hline & $\frac{\text { Bus Service }}{\underline{\text { Available }}}$ & No Bus & Total \\
\hline 0 to 99 & $20.3 \%$ & $79.7 \%$ & $100.0 \%$ \\
\hline 100 to 499 & $44.3 \%$ & $55.7 \%$ & $100.0 \%$ \\
\hline 500 to 1,499 & $70.1 \%$ & $29.9 \%$ & $100.0 \%$ \\
\hline 1,500 to 2,999 & $85.8 \%$ & $14.2 \%$ & $100.0 \%$ \\
\hline 3,000 \& up & $96.4 \%$ & $3.6 \%$ & $100.0 \%$ \\
\hline All & $63.4 \%$ & $36.6 \%$ & $100.0 \%$ \\
\hline
\end{tabular}


As housing density increases the availability of bus increases from $20.3 \%$ for block groups with 0 to 99 units to $96.4 \%$ for block groups with 3,000 or more housing units. The general availability of bus is approximately $63.4 \%$ while $36.6 \%$ of residents do not have bus service available across all housing density levels (Table 33).

TABLE 34: DISTANCE TO TRANSIT FROM THE HOUSEHOLD BY RESIDENTIAL DENSITY

\begin{tabular}{|c|c|c|c|c|c|c|}
\hline $\begin{array}{l}\text { Distance to Transit } \\
\text { from Household }\end{array}$ & 0 to 99 & $\frac{100 \text { to }}{\underline{499}}$ & $\frac{500 \text { to }}{1,499}$ & $\frac{1,500 \text { to }}{\underline{2,999}}$ & $\frac{3,000}{\& \text { up }}$ & All \\
\hline Less than .1 mile & $17.8 \%$ & $19.4 \%$ & $25.7 \%$ & $35.1 \%$ & $54.3 \%$ & $36.0^{\circ}$ \\
\hline .1 to .24 mile & $2.6 \%$ & $6.0 \%$ & $13.0 \%$ & $18.3 \%$ & $17.2 \%$ & $14.3^{\circ}$ \\
\hline .25 to .4 & $3.3 \%$ & $7.2 \%$ & $10.5 \%$ & $13.5 \%$ & $11.5 \%$ & 10.8 \\
\hline .5 to .99 mile & $19.1 \%$ & $31.2 \%$ & $36.0 \%$ & $26.9 \%$ & $14.6 \%$ & 25.1 \\
\hline 1 Mile \& up & $57.2 \%$ & $36.2 \%$ & $14.8 \%$ & $6.2 \%$ & $2.4 \%$ & 13. \\
\hline Total & $100.0 \%$ & $100.0 \%$ & $100.0 \%$ & $100.0 \%$ & $100.0 \%$ & 100. \\
\hline
\end{tabular}

For those persons having transit available the distance to transit decreases for a larger number of households in the densest block groups (Table 34). At the 0 to 99 level approximately $17.8 \%$ of households are less than .1 mile. When residential density increases up to 3,000 units $54.3 \%$ of households are less than .1 mile an increase of more than $300 \%$. At the lowest residential density there is a drop at the .1 mile to .49 mile range with a total of $5.9 \%$ of households located between those distances. These numbers change to $19.1 \%$ for households that are located beyond .5 mile of transit. At the 3,000 and up density level only $2.4 \%$ of households are located at a distance of one mile or greater from transit. While approximately $57.2 \%$ of households are located more than a mile from transit in the lowest density level. The lack of accessible transit service (within one-quarter mile) in low density residential areas means that persons living in rural areas that are transit dependent have limited or no transit alternative. The distance from the transit station or bus stop is critically important to the decision whether or not to use transit at all.

TABLE 35: MODE OF TRANSPORTATION BY RESIDENTIAL DENSITY

\begin{tabular}{|c|c|c|c|c|c|c|}
\hline \multirow[b]{2}{*}{$\begin{array}{l}\text { Mode of } \\
\text { Transportation }\end{array}$} & \multicolumn{6}{|c|}{ Block Group Residential Density (Housing Units/ Mile ${ }^{2}$ ) } \\
\hline & $\underline{0 \text { to } 99}$ & $\frac{100 \text { to }}{499}$ & $\frac{500 \text { to }}{1,499}$ & $\frac{1,500 \text { to }}{\underline{2,999}}$ & $\frac{3,000}{\& \text { up }}$ & All \\
\hline Private Vehicle & $93.2 \%$ & $92.8 \%$ & $92.2 \%$ & $90.3 \%$ & $76.0 \%$ & $89.3 \%$ \\
\hline Public Transit & $3.5 \%$ & $3.1 \%$ & $3.0 \%$ & $2.8 \%$ & $8.4 \%$ & $4.0 \%$ \\
\hline Taxi & $0.0 \%$ & $0.1 \%$ & $0.1 \%$ & $0.1 \%$ & $0.7 \%$ & $0.2 \%$ \\
\hline Bicycle/Walk & $3.3 \%$ & $4.1 \%$ & $4.7 \%$ & $6.8 \%$ & $14.9 \%$ & $6.5 \%$ \\
\hline Total & $100.0 \%$ & $100.0 \%$ & $100.0 \%$ & $100.0 \%$ & $100.0 \%$ & $100.0 \%$ \\
\hline
\end{tabular}


Table 35 reports the results of the primary mode used by respondents. They were asked to identify the mode used for the longest portion of the trip taken. The pre-dominance of the private vehicle is evident across all residential densities. The mode of transportation used by most households in the lowest density areas is the private vehicle used by $93.2 \%$ of households. Where residential density is the greatest approximately $76.0 \%$ of households use the private vehicle. The densest residential areas display significantly lower dependence on the private vehicle. The availability of transit and other modes explains some of this as well as the existence of large numbers of urban poor that do not own automobiles. Public transit is used by $8.4 \%$ of households in the densest residential areas and only $3.5 \%$ use it in the lowest density areas. The largest number of bicycle and walk trips are made by households in the densest residential areas and this is probably influenced by the proximity of trip destinations. Overall 89.3 use the private vehicle and $4 \%$ use transit.

TABLE 36: ANNUALIZED INDIVIDUAL TRAVEL BEHAVIOR BY RESIDENTIAL DENSITY

Block Group

Residential Density

(Housing Units/Mile ${ }^{2}$ )

$\begin{array}{rr}0 \text { to } 99 & 1,521 \\ 100 \text { to } 499 & 1,604 \\ 500 \text { to } 1,499 & 1,601 \\ 1,500 \text { to } 2,999 & 1,588 \\ 3,000 \text { \& up } & 1,532 \\ \text { Overall } & 1,568\end{array}$

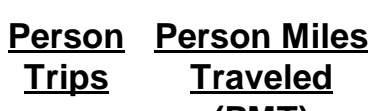

(PMT)

16,973

15,092

14,366

12,923

10,304

14,064
Annualized Individual Travel Behavior

$\begin{array}{rrr}\frac{\text { Person }}{\text { Miles per }} & & \text { Vehicle } \\ { } } & & \text { Trips } \\ 11 & 959 \\ 9 & 1,011 \\ 9 & 1,010 \\ 8 & 989 \\ 7 & 771 \\ 9 & 951\end{array}$

Vehicle Miles Traveled (VMT)

10,562

9,590

8,283

8,020

5,764

8,523
Vehicle Miles per Trip

FIGURE 5: ANNUALIZED INDIVIDUAL TRAVEL BEHAVIOR BY RESIDENTIAL DENSITY
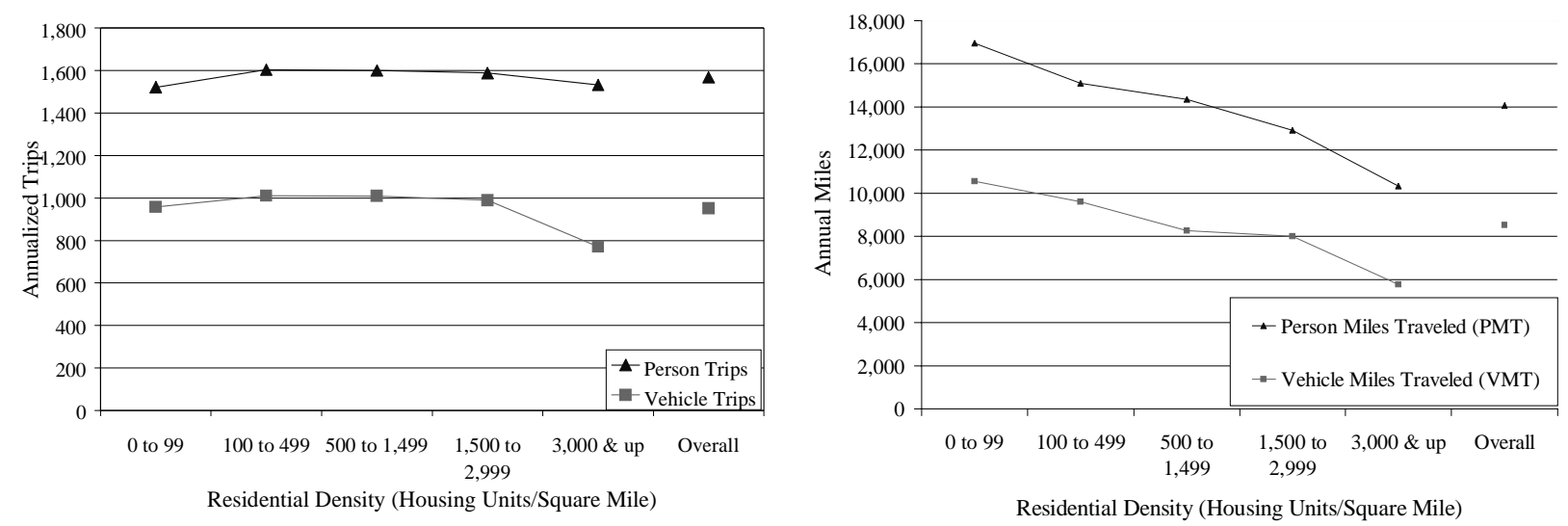
The impact of residential density on Vehicle Miles Traveled (VMT), Vehicle Trips, and Person Miles Traveled (PMT) is illustrated in Table 36. As residential density increases there is a corresponding decrease in person miles traveled, vehicle trips, and vehicle miles traveled. From the lowest density residential areas to the densest, the number of person miles traveled decreased by approximately $60.7 \%$, vehicle trips decreased by $58.35 \%$ and vehicle miles traveled decreased by $54.31 \%$. So, as residential density increased travel in all three categories experienced a sizable decrease. However, this decrease in travel as density increased was not true for person trips which increased although by only $.007 \%$. So residents made slightly more person trips in the densest residential areas but traveled fewer personal miles, made fewer vehicle trips, and reduced the total number of vehicle miles traveled. Increased residential density results in the sizable reduction in specific categories of travel.

\section{TABLE 37: WORK LOCATION BY RESIDENTIAL DENSITY}

\begin{tabular}{|c|c|c|c|c|c|c|}
\hline \multirow[b]{2}{*}{ Place of Work } & \multicolumn{6}{|c|}{ Block Group Residential Density (Housing Units/ Mile ${ }^{2}$ ) } \\
\hline & $\underline{0 \text { to } 99}$ & 100 to 499 & $\underline{500 \text { to } 1,499}$ & 1,500 to 2,999 & $\underline{3,000 \& \text { up }}$ & All \\
\hline Work from Home & $7.9 \%$ & $6.0 \%$ & $5.1 \%$ & $5.4 \%$ & $4.8 \%$ & $5.9 \%$ \\
\hline No Fixed Work Place & $2.5 \%$ & $1.7 \%$ & $1.7 \%$ & $2.5 \%$ & $2.4 \%$ & $2.2 \%$ \\
\hline Work at Work Location & $89.6 \%$ & $92.3 \%$ & $93.2 \%$ & $92.0 \%$ & $92.8 \%$ & $91.9 \%$ \\
\hline Total & $100.0 \%$ & $100.0 \%$ & $100.0 \%$ & $100.0 \%$ & $100.0 \%$ & $100.0 \%$ \\
\hline
\end{tabular}

Table 37 reports the impact of residential density on workplace choice. As residential density increases the percentage of persons working from the home decreases from $7.9 \%$ to $4.8 \%$ while the number of persons working at a work location increases from $89.6 \%$ to $92.8 \%$. This increase in employment at a work location may be attributed to a variety of sources for example, greater and more diverse employment opportunities, the availability of transit, wages, and more walk and bicycle trips.

TABLE 38: EMPLOYMENT DENSITY BY RESIDENTIAL DENSITY

\begin{tabular}{|c|c|c|c|c|c|c|}
\hline \multirow{2}{*}{$\begin{array}{c}\text { Work Tract } \\
\text { Employment Density } \\
\left.\text { (Employees per Mile }{ }^{2}\right)\end{array}$} & \multicolumn{6}{|c|}{ Block Group Residential Density (Housing Units/ Mile ${ }^{2}$ ) } \\
\hline & $\underline{0}$ to 99 & 100 to 499 & $\underline{500 \text { to } 1,499}$ & 1,500 to 2,999 & $\underline{3,000 \& \text { up }}$ & $\frac{\text { Overal }}{\underline{I}}$ \\
\hline 0 to 174 & $96.0 \%$ & $42.2 \%$ & $6.4 \%$ & $1.4 \%$ & $0.5 \%$ & $36.6 \%$ \\
\hline 175 to 799 & $1.9 \%$ & $44.8 \%$ & $40.0 \%$ & $23.2 \%$ & $7.9 \%$ & $21.0 \%$ \\
\hline 800 to 1,999 & $0.6 \%$ & $7.8 \%$ & $32.0 \%$ & $38.1 \%$ & $24.5 \%$ & $18.9 \%$ \\
\hline 2,000 to 6,499 & $0.7 \%$ & $3.6 \%$ & $17.4 \%$ & $30.3 \%$ & $42.3 \%$ & $16.8 \%$ \\
\hline $6,500 \&$ up & $0.7 \%$ & $1.6 \%$ & $4.2 \%$ & $6.9 \%$ & $24.7 \%$ & $6.7 \%$ \\
\hline Total & $100.0 \%$ & $100.0 \%$ & $100.0 \%$ & $100.0 \%$ & $100.0 \%$ & $100.0 \%$ \\
\hline
\end{tabular}


For those people who work at a fixed work location, patterns of employment density follow patterns of residential density. The data in table 38, which come from census data provided by Claritas (as opposed to NPTS data provided by the Federal Highway Administration), show trends where increasing employment density corresponds with increasing residential density. By far, areas with fewer than 100 housing units per square mile have the highest percentage of people working in areas with fewer than 175 jobs per square mile (96.0\%). Similarly, areas with over 3,000 housing units per square mile have the highest percentage of people who work in census tracts with over 6,500 employees per square mile (24.7\%). Overall, however, the largest percentage of all people work in tracts with fewer than 175 jobs per square mile (36.6\%), which could represent a turnaround trend from the days when cities as commercial centers were seen as primary employment centers.

\section{Age of Housing}

The age of housing provides another important indicator for residential area land use. New housing in an area implies population growth in that area, and transportation infrastructure must meet the needs of the population where it exists.

TABLE 39: AGE OF HOUSING BY AREA TYPE

\% of Block Group Housing Units Built in the Last Ten Years
Second City $80.6 \%$

$21-40 \%$

$41-60 \%$

$61-80 \%$

$81-100 \%$

Total $11.0 \%$

$4.8 \%$

$2.4 \%$

$1.2 \%$

$100.0 \%$

\section{Area Type}

Rura

Suburban

$87.1 \%$

$11.5 \%$

$1.3 \%$

$0.0 \%$

$0.1 \%$

$75.2 \%$
$13.0 \%$
$6.9 \%$
$3.3 \%$
$1.6 \%$
$100.0 \%$

\begin{tabular}{rrr} 
Town & Urban & \multicolumn{1}{c}{ All } \\
$70.7 \%$ & $93.5 \%$ & $80.6 \%$ \\
$19.2 \%$ & $4.8 \%$ & $12.3 \%$ \\
$6.2 \%$ & $1.5 \%$ & $4.4 \%$ \\
$2.2 \%$ & $0.2 \%$ & $1.7 \%$ \\
$1.6 \%$ & $0.1 \%$ & $1.0 \%$ \\
$100.0 \%$ & $100.0 \%$ & $100.0 \%$
\end{tabular}

New development has occurred in the last ten years primarily outside of urban and rural areas. Joel Garreau classifies edge cities as areas that were "nothing like 'city' as recently as thirty years ago $^{6}$." These development configurations started appearing in America much later than traditional urban areas. The similar concept of second city approximates edge city for the NPTS data. Presumably, housing for second cities would be remarkably young; however, the NPTS data do not indicate substantial youth for second cities compared to town and suburban areas. Town and suburban areas have been developed more recently, with only $29.3 \%$ and $24.8 \%$ of their block groups respectively containing over $20 \%$ housing built in the last ten years. This is $19.4 \%$ in second cities. Suburban areas, where $11.8 \%$ of the block groups constructed $40 \%$ of their housing units in the last ten years, have the highest percentage of very young communities. Existing housing structure in urban and rural areas has maintained a substantially dominant presence with $93.5 \%$ and $87.1 \%$ of block groups containing less than $20 \%$ housing units built in the last ten years (Table 39). 
TABLE 40: BUS AVAILABILITY FOR RECENT BUILDS

\begin{tabular}{|c|c|c|c|c|c|c|}
\hline \multirow{2}{*}{$\begin{array}{c}\text { Bus } \\
\text { Availability }\end{array}$} & \multicolumn{6}{|c|}{$\%$ of Block Group Housing Units Built in Last 10 Years } \\
\hline & $0-20 \%$ & $21-40 \%$ & 41-60\% & $\underline{61-80 \%}$ & $81-100 \%$ & All \\
\hline $\begin{array}{r}\text { Bus Service } \\
\text { Available }\end{array}$ & $64.4 \%$ & $54.8 \%$ & $65.9 \%$ & $72.9 \%$ & $67.1 \%$ & \\
\hline No Bus & $35.6 \%$ & $45.2 \%$ & $34.1 \%$ & $27.1 \%$ & $32.9 \%$ & 36.6 \\
\hline Total & $100.0 \%$ & $100.0 \%$ & $100.0 \%$ & $100.0 \%$ & $100.0 \%$ & $100.0 \%$ \\
\hline
\end{tabular}

Public transit infrastructure develops over a multi-year process. Established urban areas implemented sophisticated public transit decades ago. Newer towns experiencing high growth may find themselves facing heavy need for transit before infrastructure can be developed. Urban and rural areas have the highest percentages of block groups with less than $20 \%$ housing built in the last ten years. Urban areas have well-established transit systems with $98.3 \%$ of the population served by transit; with just $14.3 \%$ of rural residents claiming transit availability, rural areas have little transit infrastructure.

Transit infrastructure appears to meet new demand. All block groups with over $40 \%$ housing units built in the last ten years surpass the overall average of $63.4 \%$ of the people served by transit. Areas with between 61 and $80 \%$ new housing units achieve the highest level of transit availability with $72.9 \%$ of the population of these areas served (Table 40 ).

\section{Housing Tenure}

Age of housing represents a physical depiction of an area's growth; housing tenure indicates a population characteristic integral to an area's residential land use. Knowing whether residents rent or own their homes may provide insight into the stability of the area or the likelihood of residents to own a personal vehicle or utilize public transit.

TABLE 41: PERCENTAGE OF RENTER-OCCUPIED HOUSING BY AREA TYPE

\section{Renter-Occupied Housing \\ in the Block Group}

$0-9 \%$

$10-19 \%$

$20-29 \%$

$30-49 \%$

$50-100 \%$

Total

\section{Second City}

$9.7 \%$

$15.1 \%$

$15.3 \%$

$25.3 \%$

$34.6 \%$

$100.0 \%$
Area Type

\begin{tabular}{rrrrr} 
Rural & Suburban & Town & Urban & \multicolumn{1}{c}{ All } \\
\cline { 2 - 5 } $4.9 \%$ & $25.4 \%$ & $15.9 \%$ & $4.9 \%$ & $13.1 \%$ \\
$45.1 \%$ & $22.0 \%$ & $29.4 \%$ & $9.3 \%$ & $24.7 \%$ \\
$30.5 \%$ & $15.8 \%$ & $21.1 \%$ & $9.7 \%$ & $18.7 \%$ \\
$17.4 \%$ & $18.6 \%$ & $23.0 \%$ & $18.6 \%$ & $20.6 \%$ \\
$2.1 \%$ & $18.2 \%$ & $10.5 \%$ & $57.5 \%$ & $23.0 \%$ \\
$100.0 \%$ & $100.0 \%$ & $100.0 \%$ & $100.0 \%$ & $100.0 \%$
\end{tabular}


As shown in Table 41, area type appears to influence the amount of renter-occupied housing. Urban areas have high rental capacity. Second cities have more rental housing than less densely populated areas but less rental housing than urban areas provide. The largest concentration of rental units in rural areas, $45.1 \%$, occurs in block groups containing between 10 and $19 \%$ of rental units. Rural areas match urban areas with only $4.9 \%$ of block groups containing less than $10 \%$ rental housing. More than $75 \%$ of all rural block groups contain between 10 and $29 \%$ rental units. Towns also show a peak at 10 to $19 \%$, but towns have a more even spread that includes $33.5 \%$ of block groups with 30 to $100 \%$ renter-occupied housing.

\begin{tabular}{|c|c|c|c|}
\hline \multirow[b]{2}{*}{ Housing Tenure } & \multicolumn{2}{|c|}{ Transit Availability } & \multirow[b]{2}{*}{$\underline{\text { Total }}$} \\
\hline & $\frac{\text { Bus Service }}{\text { Available }}$ & No Bus & \\
\hline Owned & $57.9 \%$ & $42.1 \%$ & $100.0 \%$ \\
\hline Rented & $77.2 \%$ & $22.8 \%$ & $100.0 \%$ \\
\hline Provided By Job or Military & $50.7 \%$ & $49.3 \%$ & $100.0 \%$ \\
\hline Other & $64.7 \%$ & $35.3 \%$ & $100.0 \%$ \\
\hline All & $63.3 \%$ & $36.7 \%$ & $100.0 \%$ \\
\hline
\end{tabular}

As shown in Table 42, public transit serves $50 \%$ or more of all housing types. Transit is most closely associated with rental communities, where $77.2 \%$ of renters have access to bus service. Rental communities typically include more people without personally owned vehicles compared to communities where home ownership is more common. Approximately 58\% of communities have available bus service in areas where home ownership prevails.

TABLE 43: DISTANCE TO TRANSIT BY HOUSING TENURE

\begin{tabular}{|c|c|c|c|c|c|}
\hline \multirow[b]{2}{*}{$\frac{\text { Distance to }}{\text { Transit from }}$} & \multicolumn{5}{|c|}{ Housing Tenure } \\
\hline & Owned & Rented & $\begin{array}{l}\text { Provided } \\
\frac{\text { By Job or }}{\text { Military }}\end{array}$ & Other & All \\
\hline Less than .1 mile & $29.0 \%$ & $49.2 \%$ & $30.3 \%$ & $65.4 \%$ & $36.0 \%$ \\
\hline .1 to .24 mile & $14.2 \%$ & $14.5 \%$ & $6.7 \%$ & $12.0 \%$ & $14.3 \%$ \\
\hline .25 to .49 mile & $11.6 \%$ & $9.4 \%$ & $1.8 \%$ & $0.0 \%$ & $10.8 \%$ \\
\hline .5 to .99 mile & $28.0 \%$ & $19.6 \%$ & $48.9 \%$ & $17.2 \%$ & $25.1 \%$ \\
\hline 1 Mile \& up & $17.2 \%$ & $7.3 \%$ & $12.4 \%$ & $5.4 \%$ & $13.7 \%$ \\
\hline Total & $100.0 \%$ & $100.0 \%$ & $100.0 \%$ & $100.0 \%$ & $100.0 \%$ \\
\hline
\end{tabular}


Renters live closer to transit than owners. Of the $77.2 \%$ of renters reporting bus service available to them, $49.2 \%$ live within one-tenth of a mile of bus service. Only $29 \%$ of served owners report that proximity to transit, but even $82.8 \%$ of owners with bus service available to them live within one mile of transit. The typically dense nature of rental housing may explain why renters receive better service from public transit: one bus route can easily provide transportation for a large number of renters located in a small area (Table 43).

With only half of the community living in homes provided by employers or the military receiving transit service, $48.9 \%$ of this segment of the community lives between one half and one mile away from bus service. Another $30.3 \%$ of this community lives less than one-tenth of a mile away from transit. These figures resemble transit availabilities for owner more than for renters. Military personnel may live on bases which provide self-contained communities without need for extensive transportation to non-military locations.

\section{Measures for Employment}

\section{Employment Density}

TABLE 44: WORK TRACT EMPLOYMENT DENSITY BY HOME BLOCK GROUP AREA TYPE

Work Tract Employment Density (Workers per Mile')

0 to 174
175 to 799
800 to 1,999
2,000 to 6,499
$6,500 \&$ up
Total

\begin{tabular}{rr} 
Second City & Rural \\
\hline $15.4 \%$ & $60.7 \%$ \\
$20.8 \%$ & $16.4 \%$ \\
$23.8 \%$ & $10.8 \%$ \\
$23.1 \%$ & $8.2 \%$ \\
$16.9 \%$ & $3.9 \%$ \\
$100.0 \%$ & $100.0 \%$
\end{tabular}

Area Type

\begin{tabular}{rrrr} 
Suburban & Town & Urban & \multicolumn{1}{l}{ All } \\
\cline { 4 - 5 } $6.0 \%$ & $32.3 \%$ & $1.7 \%$ & $22.5 \%$ \\
$17.9 \%$ & $25.9 \%$ & $6.5 \%$ & $18.3 \%$ \\
$23.4 \%$ & $16.0 \%$ & $13.9 \%$ & $18.2 \%$ \\
$29.5 \%$ & $16.5 \%$ & $32.3 \%$ & $22.2 \%$ \\
$23.1 \%$ & $9.3 \%$ & $45.6 \%$ & $18.9 \%$ \\
$100.0 \%$ & $100.0 \%$ & $100.0 \%$ & $100.0 \%$
\end{tabular}


FIGURE 6: WORK TRACT EMPLOYMENT DENSITY BY HOME BLOCK GROUP AREA TYPE

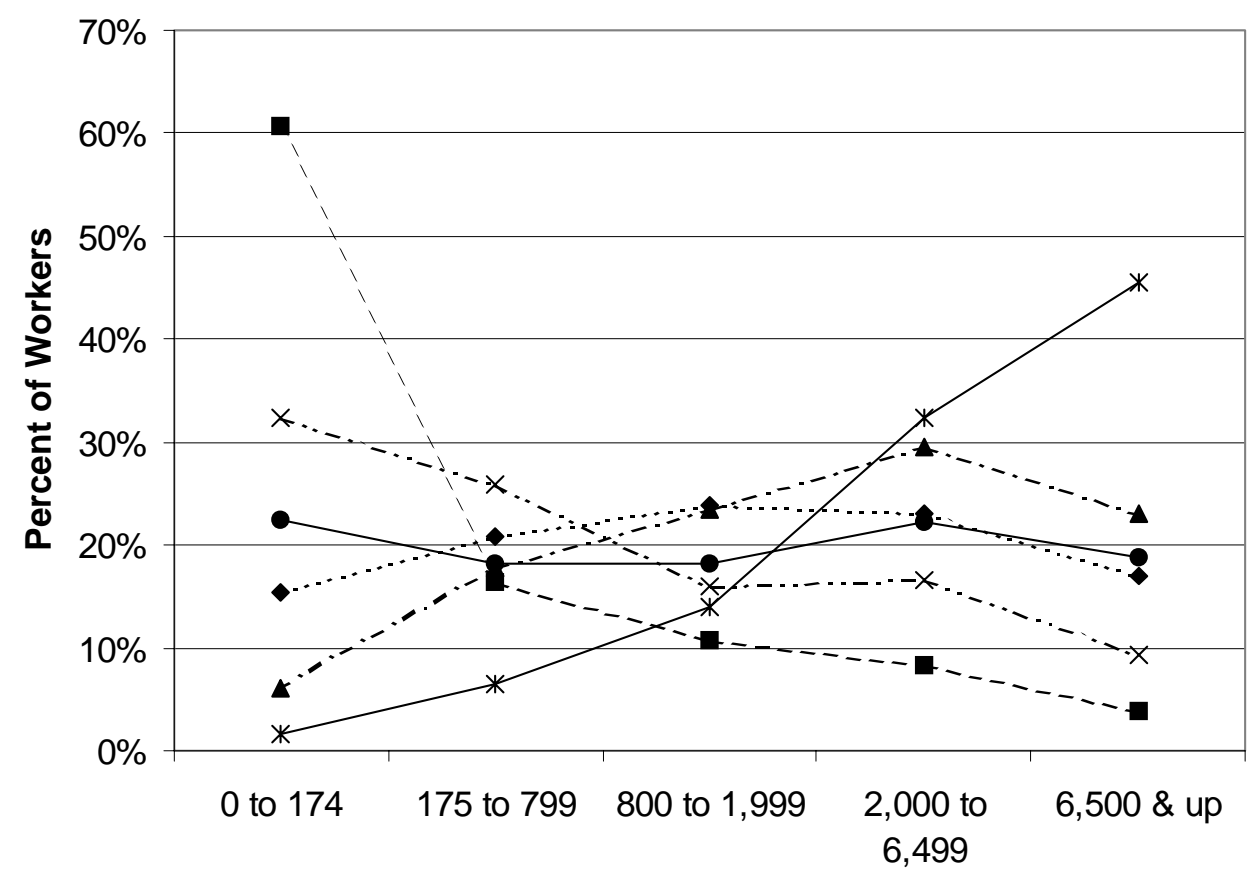

Work Tract Employment Density (Workers/Square Mile)

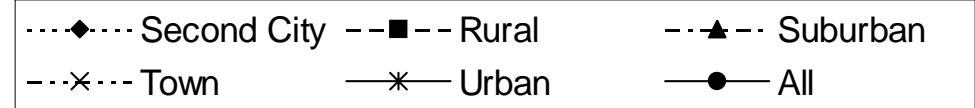

The NPTS data indicate that employment density patterns and population density patterns typically mirror one another. People living in rural areas tend to work in areas of low employment density. People living in urban areas tend to work in areas of high employment density. A graph of work tract employment densities shows striking difference in trend lines according to area type. The trend line for urban areas sweeps up as work tract employment density increases, while the trend line for rural areas turns downward. The trend line for town residents decreases with a downward slope not as steep as the slope for the rural trend line.

Trend lines for residents of suburbia and second cities display employment location decisions similar to each other. These trend lines include maximum values. Percentages of second city residents working in tracts with low employment densities increase as employment densities increase, up to a maximum value with $23.8 \%$ of second city residents working in census tracts with employment densities from 800 to 1,999 jobs per square mile. A lower percentage of second city residents work in tracts with higher employment densities. Employment density for suburban residents reaches a maximum value with $29.5 \%$ of suburban residents working in tracts with employment densities from 2,000 to 6,499 jobs per square mile; fewer suburban residents work in tracts with over 6,500 jobs per square mile. 
The graphed trend lines translate easily into indications of density preference. Urban residents live in areas of high population density and, presumably, live near an area of high employment density; therefore, $45.6 \%$ of urban residents work in tracts with over 6,500 jobs per square mile. Rural residents live in sparsely developed areas where job densities remain low. Approximately $60.7 \%$ of rural residents work in tracts with less than 175 jobs per square mile (Table 44).

\section{TABLE 45: MILES DRIVEN LAST YEAR BY EMPLOYMENT DENSITY AND GENDER}

\begin{tabular}{|c|c|c|c|c|}
\hline \multirow{3}{*}{$\begin{array}{c}\text { Work Tract } \\
\text { Employment Density } \\
\left.\text { (Employees per Mile }{ }^{2}\right)\end{array}$} & \multicolumn{4}{|c|}{ Annual Miles Driven } \\
\hline & \multicolumn{2}{|c|}{ Male } & \multicolumn{2}{|c|}{ Female } \\
\hline & Mean & Median & Mean & Median \\
\hline 0 to 174 & 19,367 & 15,000 & 11,277 & $\overline{10,000}$ \\
\hline 175 to 799 & 18,399 & 15,000 & 11,144 & 10,000 \\
\hline 800 to 1,999 & 17,466 & 15,000 & 10,956 & 10,000 \\
\hline 2,000 to 6,499 & 16,537 & 15,000 & 10,895 & 10,000 \\
\hline $6,500 \&$ up & 14,543 & 12,000 & 10,353 & 10,000 \\
\hline
\end{tabular}

Females do not change their travel behavior as drastically as males do as employment density at the work tract changes. Males working in low employment densities from 0 to 174 employees per square mile annually drive an average of 19,367 miles while females drive 11,277 miles (Table 45).

TABLE 46: ONE-WAY WORK TRIP BY EMPLOYMENT DENSITY AND GENDER
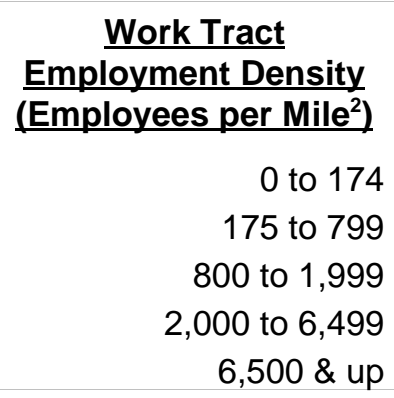

\section{Distance to Work (Miles) \\ Male \\ Female} Mean Median

12

12

13

13

15
Mean Median

7

8

8

$9 \quad 10$

$10 \quad 13$

96

96

$10 \quad 7$

$10 \quad 7$

139

\begin{tabular}{|c|c|c|c|}
\hline \multicolumn{4}{|c|}{ Time to Work (Minutes) } \\
\hline \multicolumn{2}{|c|}{ Male } & \multicolumn{2}{|c|}{ Female } \\
\hline Mean & Median & Mean & Median \\
\hline 18 & 15 & 15 & 11 \\
\hline 20 & 15 & 17 & 15 \\
\hline 22 & 15 & 19 & 15 \\
\hline 23 & 20 & 21 & 15 \\
\hline 30 & 25 & 28 & 24 \\
\hline
\end{tabular}

People live farther away from work when the workplace is located in a tract with high employment density than when the workplace is located in a tract with low employment density. The distance from home to the workplace does not vary by much; however, distance consistently increases for both men and women as employment density increases. Men working in work tracts with over 6,500 jobs per square mile commute 15 miles to work on average, which is 3 miles more than men who work in work tracts with under 175 jobs per square mile. Females 
working in high density work tracts commute 4 miles more on an average one-way trip to work than females working in low-employment density work tracts.

Average commute times for both men and women almost double, going from 18 minutes in a low-employment density area to 30 minutes in a high-employment density area for males and going from 15 minutes in a low-employment density area to 28 minutes in a high-employment density area for females. This strong increase in commute time may be attributable to the increased traffic encountered in areas of high-employment density during peak hours (Table 46).

\section{Retail Employment}

Employment density gives indications for travel behavior for all workplaces. Dissecting employment by Standard Industrial Classification (SIC) codes can offer a more refined view of how certain industries affect an area's transportation. This refined view becomes increasingly important when one or two industries dominate an area's employment.

TABLE 47: RETAIL TRADE BY AREA TYPE

\begin{tabular}{|c|c|c|c|c|c|c|}
\hline \multirow{2}{*}{$\begin{array}{l}\text { Percent of the Work } \\
\text { Tract's 16+ Population } \\
\text { Working in Retail Trade }\end{array}$} & \multicolumn{6}{|c|}{ Home Block Group Area Type } \\
\hline & Second City & Rural & Suburban & Town & Urban & All \\
\hline 0 to $9 \%$ & $28.3 \%$ & $23.5 \%$ & $31.4 \%$ & $26.7 \%$ & $38.8 \%$ & $29.5 \%$ \\
\hline 10 to $14 \%$ & $16.8 \%$ & $23.4 \%$ & $18.7 \%$ & $18.5 \%$ & $19.1 \%$ & $19.2 \%$ \\
\hline 15 to $24 \%$ & $26.2 \%$ & $32.1 \%$ & $25.4 \%$ & $29.6 \%$ & $23.8 \%$ & $27.4 \%$ \\
\hline $25 \%$ \& up & $28.8 \%$ & $21.0 \%$ & $24.5 \%$ & $25.2 \%$ & $18.2 \%$ & $23.9 \%$ \\
\hline Total & $100.0 \%$ & $100.0 \%$ & $100.0 \%$ & $100.0 \%$ & $100.0 \%$ & $100.0 \%$ \\
\hline
\end{tabular}

Economists historically started defining American cities with a monocentric model in which all development formed around a central business district. Retail employment has traditionally been associated with urban areas. The metamorphosis of American land use has resulted in malls and retail areas on the outer edges of metropolitan areas and outside cities. The 1995 NPTS shows the plurality of workers living in urban block groups (38.8\%) work in census tracts with less than $10 \%$ of the population working in retail trade. Urban areas also have the smallest percentage of workers $(18.2 \%)$ who are employed in tracts with over $25 \%$ retail trade participation. Second cities have taken the lead in retail trade where $28.8 \%$ of residential block groups have residents who work in tracts with over $25 \%$ of their employees working in retail. Rural areas follow closely with where $32.1 \%$ of the workforce of rural block groups working where 15 to $24 \%$ of jobs are in retail (Table 47). 


\begin{tabular}{|c|c|c|c|c|}
\hline \multirow{3}{*}{$\begin{array}{l}\text { Percent of the Work } \\
\text { Tract's 16+ Population } \\
\text { Working in Retail Trade }\end{array}$} & \multicolumn{4}{|c|}{ Annual Miles Driven } \\
\hline & \multicolumn{2}{|c|}{ Male } & \multicolumn{2}{|c|}{ Female } \\
\hline & Mean & Median & Mean & Median \\
\hline 0 to $9 \%$ & 17,184 & 14,000 & 10,788 & 10,000 \\
\hline 10 to $14 \%$ & 18,164 & 15,000 & 11,225 & 10,000 \\
\hline 15 to $24 \%$ & 17,184 & 15,000 & 10,797 & 10,000 \\
\hline $25 \%$ \& up & 17,077 & 15,000 & 11,044 & 10,000 \\
\hline
\end{tabular}

The percent of retail employment in one's work census tract does not appear to affect an individual's annual mileage driven. The median annual mileage for females remains constant at 10,000 miles, regardless of work tract retail employment. For males, median miles decrease from 15,000 miles annually to 14,000 miles annually when census tract participation in retail trade falls below $10 \%$. This slight variation does not appear significant since mean mileage is fairly consistent. The results suggest retail employment in the work tract does not affect annual driving distances (Table 48).

TABLE 49: ONE-WAY WORK TRIP BY RETAIL EMPLOYMENT AND GENDER

\begin{tabular}{|c|c|c|c|c|c|c|c|c|}
\hline \multirow{3}{*}{$\begin{array}{l}\text { Percent of the Work } \\
\text { Tract's 16+ Population } \\
\text { Working in Retail Trade }\end{array}$} & \multicolumn{4}{|c|}{ Distance to Work (Miles) } & \multicolumn{4}{|c|}{ Time to Work (Minutes) } \\
\hline & \multicolumn{2}{|c|}{$\underline{\text { Male }}$} & \multicolumn{2}{|c|}{ Female } & \multicolumn{2}{|c|}{ Male } & \multicolumn{2}{|c|}{ Female } \\
\hline & Mea & Media & Mea & Media & Mea & Media & Mea & Media \\
\hline & $\underline{\mathbf{n}}$ & $\underline{\mathbf{n}}$ & $\underline{\mathbf{n}}$ & $\underline{\mathbf{n}}$ & $\underline{\mathbf{n}}$ & $\underline{\mathbf{n}}$ & $\underline{\mathbf{n}}$ & $\underline{\mathbf{n}}$ \\
\hline 0 to $9 \%$ & 14 & 10 & 11 & 8 & 25 & 2 & 23 & 20 \\
\hline 10 to $14 \%$ & 13 & 9 & 10 & 7 & 23 & 1 & 21 & 15 \\
\hline 15 to $24 \%$ & 13 & 8 & 10 & 6 & 21 & 1 & 19 & 15 \\
\hline $25 \%$ \& up & 12 & 7 & 10 & 6 & 19 & 1 & 18 & 15 \\
\hline
\end{tabular}

Retail employment may, however, provide some effect on work trips. High participation in the retail workforce seems to indicate shortened commutes in terms of both distance and time. Males working in census tracts with over $25 \%$ of the jobs in retail trade commute two miles fewer than males working in census tracts with under $10 \%$ retail employment. This two-mile reduction in commute distance results in a six-minute reduction in commute time. Females correspondingly reduce their commutes by one mile or five minutes. Retail industries typically begin their workdays after the morning peak period and often end their workdays after evening peak periods. People commuting in areas with a high percentage of retail trade will find the population's commutes spread over a longer period of time than the typical peak period and commuters will encounter fewer delays due to congestion. 


\section{FINDINGS AND CONCLUSIONS}

\section{Measures for People}

Greater population density is associated with a number of travel outcomes including decreasing annual miles driven for both genders for all population densities. This is most certainly affected by the fact that bus availability increases with population density offering other travel choices for urban residents. The existence of transit in more dense populations is associated with fewer miles driven and transit is located most closely to households in the most densely populated areas. Clearly increased density is highly correlated with decreased dependency on the single occupancy vehicle resulting in fewer annual miles driven. People in lower density areas travel longer distances to work and have longer commute times, however recently the most densely populated areas are showing an increase in commute times. To some extent this is attributable to increasing congestion levels in urban areas.

Less densely populated areas tend to have more drivers per adult and more vehicles per adult. The lack of available travel options (modes) explains some of this. The private automobile dominates as the most preferred mode of travel but the use of transit increases as population density increases. Therefore we see greater reliance on the use of the automobile where travelers have few or no alternatives for traveling. Whites are more heavily dependent on the single occupancy vehicle than are other races. African Americans and Hispanics are slightly more likely to use other forms of transportation. Transit availability is below average for whites and above average for African Americans, Asians and Hispanics. Transit availability is generally associated with increases in educational attainment. As educational levels increase these persons tend to locate where they have more access to transit.

Wealthier households are most prevalent in suburban areas, middle income households are most common in rural areas, and households with the lowest incomes are most common in second city, urban and rural areas. Areas with the greatest percent of block groups living in poverty tend to have the greatest accessibility (least distance) to transit.

Households with no children and a working-age adult to locate most closely to transit, while families with children under 16 generally live farther from transit. Younger workers tend to have shorter work trip distances and trip times, regardless of gender and females have shorter work trip distances than males across all age groups. Cities attract young adults, both single and married, who have no children; families with children tend to live in suburban areas and towns while the elderly have their greatest presence in second cities.

Increasing density is associated with fewer person trips, person miles traveled (PMT) and person miles per trip. Vehicle trips, vehicle miles traveled (VMT) and vehicle miles per trip are all lowest in the most densely populated areas. Increased densification is one way to reduce miles traveled although the critical question is what level of density would be necessary to cause a significant reduction in miles traveled or a substantial increase in transit usage. 


\section{Measures for Places}

\section{Area Type}

Controlling for area type revealed several correlations between land use and transportation. These new NPTS data which quantify travel characteristics by area type for the first time help identify and verify important trends in the interaction of urban form and travel behavior. Rural, urban and second city areas show noteworthy travel characteristics.

Rural area residents depend heavily on private transportation. They make fewer person trips than almost any other area residents in the country, yet their annual person miles traveled surpass the residents of other areas. Vehicle trips show a similar pattern. Rural areas lead with the highest ratio of young drivers to the adult population, and over one quarter of the residents own more than one vehicle per adult. Rural areas have a lower than average percentage of workers who go to work by private auto, but these areas also have the highest percentage of people who work from home, which indicates either preference or a lack of mobility. Only $14.3 \%$ of rural residents have access to transit service, compared to a national average of $63.4 \%$. For over half of those people who do have transit in their rural areas, bus service does not reach closer than one mile from home.

Urban areas can be described at the opposite end of the spectrum. These areas lead with almost a third of the population having less than one driver per adult and less than two percent of the population having more than one driver per adult. Almost half of urban residents share private vehicles or live without them. Urban workers commute across the shortest distances of anyone, but the time length of their work trips slightly exceeds the duration commute trips in other areas.

Urbanites enjoy an array of transportation options, including transit, which is available for $98.3 \%$ of the urban population. Over half of these residents have access to transit within one tenth of a mile of their homes. Even with transit options available, $69.4 \%$ of urban workers commute to work in an auto. This number represents less auto commuting than the national average of $75.9 \%$, but it also expresses a strong preference for commuters to take an auto to work.

Urban dwellers reported the lowest number of person trips of anyone. Urban residents reported driving just over half as many vehicle miles annually as rural residents. Urbanites cover less distance in vehicles than people from any other area type.

Second cities, here defined as areas of concentrated population density with population centers less dense than the core found in urban areas (see Key Terms and Definitions), have aroused a great deal of interest in recent years. While edge city population and employment clustering has been happening over decades, categorizing this new development phenomena has proven challenging. The 1995 NPTS shows why: second cities display characteristics of several of the other area types. 
In some contexts, second cities follow national averages. For $80 \%$ of the population of second cities, there is one driver for every adult, and there is one vehicle for each adult for $61.6 \%$ of the population, which is slightly higher than the national average. Second cities follow the national average for the percentage of workers working from home and the percentage of workers working at a fixed workplace. Unlike urban and rural areas, where less than $70 \%$ of the workers commute to work by auto, second city residents resemble the people of suburban areas in terms of auto dependency for their commutes. Only $20 \%$ of second city residents go to work by a mode other than a private automobile.

In other respects, second cities resemble traditional urban areas. Second city workers find employment at distances from work equivalent to the distances that urban workers traverse, but the commute for second city residents takes between five and seven minutes less time (between one fifth and one fourth of the travel time).

Second city residents reported the highest number of person trips of any area type. The next highest number of person trips came from suburban areas. Person miles traveled and vehicle miles traveled by second city residents fell short of the national average. Second city residents make frequent short trips.

In many ways, second cities represent a middle ground between urban and rural areas. Approximately $82 \%$ of second city residents have bus service available to them, which is a far higher percentage than for people in towns and rural areas but a lower percentage than for urban and suburban residents. Those second city residents who have transit service available to them typically live close to transit: $37.9 \%$ live within one tenth of a mile of transit, which is a far higher percentage than in rural, suburban, and town areas.

Second cities will continue to provide transportation challenges. People living in second cities enjoy the benefits of agglomeration, but they also prefer easy access to open spaces. The conveniences of a thriving small city atmosphere quickly grows into a transportation challenge when attempting to meet the needs of diverse residents. For instance, NPTS data indicate a high percentage of low-income residents already live in second cities. Without the extensive transit coverage that already exists in urban areas, the growing numbers of people who cannot afford private vehicles will have a difficult time surviving in automobile-dependent second city communities. Traffic congestion in these areas provides another challenge. Finding transportation alternatives for these communities to meet their needs while maintaining the in-between character of second cities poses a creative challenge to all transportation professionals.

\section{Residential Density}

As might be expected, high residential densities typically occur in urban areas and low residential densities typically occur in rural areas. About two thirds of second city and suburban people live where residential densities range between 500 and 2,999 housing units.

Travel distances, including annual miles driven, commute trip length, person miles, and vehicle 
miles, decrease as residential density increases. Interestingly, the distribution of commute time for males is U-shaped, indicating longer trips at the lowest and highest residential densities. Likewise, person trips and vehicle trips for both genders increase to a maximum value and then decrease as residential density increases. People in areas of medium residential density make the highest number of trips and have the longest commutes. Males in these areas have the longest commute times.

Transit availability and residential density share a positive correlation. Increasing housing density is associated with greater transit availability and closer proximity to transit. The availability of alternative transportation facilities reflects itself in mode choice. People living in higher residential densities rely less on private vehicles for trip-making than their counterparts living in lower residential densities do. Bicycle and walk trips increase as residential density increases.

Residential density correlates to some degree with employment, as well. Increasing employment density is associated with increasing residential density. Residential density does not correspond greatly with place of work decisions, but some slight variation exists. At residential densities between 100 and 1,499 housing units per square mile, people are less likely to work at an unfixed workplace. Low residential density areas have the greatest percentage of people who work at home.

\section{Age of Housing}

The age of housing provides an indicator for the growth or decline in an area. New housing in an area implies population growth and increased transportation demand. Second cities, which are relatively new phenomena, should be expected to have a high proportion of recent builds. In fact, second cities, towns, and suburban areas have the greatest proportion of housing built in the last ten years. Urban and rural communities established the base of their housing infrastructure prior to the last decade.

Implementing transportation strategies for new communities poses a challenge to keep pace with growth. Data show that new builds are receiving transit service. Approximately, $72.9 \%$ of the people who live in block groups comprised of 61-80\% housing units built in the last ten years have bus service. The least amount of bus service available (54.8\%) occurs in block groups with 21-40\% new builds. Transportation planners are generally meeting the demands of growth where development is concentrated.

\section{Housing Tenure}

Housing tenure offers an indication of the likelihood of community residents to use transit. Public transit serves over $50 \%$ of all housing types, but transit is most closely associated with rental communities, where $77.2 \%$ of the residents have transit availability. Rental units, which are typically densely oriented, are easy for transit to serve. Urban areas have the highest percentages of renter-occupied housing compared to other area types. Non-rental units are typically located in suburban areas. 


\section{Measures for Employment}

Urban residents live in areas with high employment density and rural and town residents work in areas with lower employment densities. Second city and suburban residents work in areas with moderate employment density. However, the annual miles driven decreases for both genders as work tract employment density increases. In addition, distance to work and time to work increase for both men and women as employment density increases. The increased availability of other modes of travel in densely populated areas, including the walk mode, would suggest decreasing travel and commute times but the role of congestion must be considered.

Distance to work and travel time to work decrease as the percentage of retail trade in an area increases. Urban areas have the smallest percentage (18.2\%) of block groups with over $25 \%$ retail trade, second cities have taken the lead in retail trade with $28.8 \%$ of block groups in second cities having over $25 \%$ of their population in retail. Rural areas have $32.1 \%$ of rural block groups with 15 to $24 \%$ of their populations working in retail.

\section{OTHER RESEARCH}

The land use special report for the 1995 NPTS provides a starting point for research in several directions. Further work with the 1995 NPTS may include a closer look at the integrated effect of land use and population variables. For instance, do particular races in urban areas have to pay to park more than others? Does a parking fee affect mode choice for urban African Americans? For urban Hispanics?

Other aspects of these data can be broadened. Now that employment density has been established as a standard for land use studies, this variable can be further integrated into descriptions of areas. This report explored the effects of employment density and retail employment on travel behavior. Other areas of employment should also receive attention to determine how to meet the needs of communities based upon their employment centers. The changing Standard Industrial Classification (SIC) system will provide some interesting data in this regard.

Future studies of land use and transportation should refine and expand independent variables. Zoning, for example, will provide another interesting dimension to this exploration. Selfreporting of land use characteristics should provide a good indication. Also, integrating NPTS data with geographic information systems (GIS) in the future will open new areas of exploration.

The issue of how land use interacts with transportation opens more questions than one report can possibly answer. This report endeavored to explore some initial areas of interest and lay a foundation for future research in this area. 


\section{REFERENCES}

Brindle, Ray, "Lies, Damned Lies and 'Automobile Dependence," Australian Transport Research Forum, Volume 19, pp. 117-131.

California Air Resources Board; The Land Use and Transportation Linkage; Office of Strategic Planning; Sacramento, CA.

Cervero, Robert, "Land Use Mixing and Suburban Mobility," Transportation Quarterly, 1988.

Cervero, Robert, "Jobs-Housing Balancing and Regional Mobility,” JAPA, Spring, 1989, pp. 136-150.

Ferguson, Erik, "Recent Nationwide Declines in Carpooling," 1990 Nationwide Personal Transportation Survey: Travel Mode Special Reports, US Department of Transportation Federal Highway Administration, December 1994.

Frank, Lawrence D. \& Pivo, Gary, "Impacts of Mixed Use and Density on Utilization of Three Modes of Travel: Single-Occupant Vehicle, Transit, and Walking," Transportation Research Record, No. 1466, 44, 1994.

Garreau, Joel, Edge City: Life on the New Frontier, Doubleday, New York, 1998.

Lave, Charles and Crepeau, Richard, "Travel by Households Without Vehicles," 1990 Nationwide Personal Transportation Survey: Travel Mode Special Reports, US department of Transportation Federal Highway Administration, December 1994.

Newman, Peter W. G. and Kenworthy, Jeffrey R., "Gasoline Consumption and Cities: A Comparison of US Cities with a Global Survey," APA Journal, Winter, 1989, pp. 24-37.

USDOT, "Edge City and ISTEA: Examining the Implications of Suburban Development Patterns," 1992. 
1. Gordon, Peter and Richardson, Harry W., Geographic Factors Explaining Work Trip Length Changes," 1990 Nationwide Personal Transportation Survey: Special Reports on Trip and Vehicle Attributes, US Department of Transportation Federal Highway Administration, February 1995, Chapter 2

2. Garreau, Joel, Edge City: Life on the New Frontier, Doubleday, New York, 1998, pp. 6-7.

3. Miller, David R. and Hodges, Ken, "A Population Density Approach to Incorporating an Urban-Rural Dimension into Small Area Lifestyle Clusters," paper presented at the Annual Meeting of the Population Association of America, Miami, Florida, May 4-7, 1994.

4. Lave, Charles and Crepeau, Richard, "Travel by Households without Vehicles," 1990 Nationwide Personal Transportation Survey: Travel Mode Special Reports, US Department of Transportation Federal Highway Administration, December 1994, Chapter 1, p. 24.

5. Ferguson, Erik, "Recent Nationwide Declines in Carpooling," 1990 Nationwide Personal Transportation Survey: Travel Mode Special Reports, US Department of Transportation Federal Highway Administration, December 1994, Chapter 2, p. 18.

6. Garreau, ibid. 